\title{
AYASOFYA-I KEBÎR CAMII ŞERÎFi HAT LEVHALARI VE KITÂBELERINDE YER ALAN HADIS METINLERI ÜZERINE BiR DEĞERLENDIRME
}

An Evaluation on the Hadith Texts Included in Calligraphy

Plates and Inscriptions of the Hagia Sophia Mosque

\section{Recep ERTUĞAY}

Dr. Öğr. Üyesi, Atatürk Üniversitesi İlahiyat Fakültesi, Hadis Anabilim Dalı. Erzurum / Türkiye

$\mathrm{PhD}$, Atatürk University Faculty of Divinity, Department of Hadith

Erzurum / Turkey

recepertugay@hotmail.com

ORCID ID: 0000-0001-7289-0338

Makale Bilgisi / Article Information

Makale Türü / Article Type: Araştırma Makalesi / Research Article

Geliş Tarihi / Date Received: 3 Kasım / 3 November 2021

Kabul Tarihi / Date Accepted: 29 Kasım / 29 November 2021

Yayın Sezonu / Pub Date Season: Aralık / December

Atıf / Citation: Recep Ertuğay “Ayasofya-I Kebîr Camii Şerîfi Hat Levhalari Ve Kitâbelerinde Yer Alan Hadis Metinleri Üzerine Bir Değerlendirme”, Bayburt Üniversitesi İlahiyat Fakültesi Dergisi, 14 (Kış) 2021: 81-107, doi: 10.47098/bayburt-ilahiyat.1018532 


\title{
Öz
}

İstanbul'un simgelerinden biri olan Ayasofya, 916 yıl kilise, fetihle birlikte 481 yll cami, 86 yıl da müze olarak kullanılmıș ve 2020'de yeniden camiye dönüștürülmüștür. İstanbul'un Fatih Sultan Mehmet tarafından fethedilmesinin ardından kiliseden camiye dönüştürülen Ayasofya'ya geçmişten günümüze bazı eklemelerde bulunulmuştur. Bu eklemelerin önemli bir unsuru da hat levhaları ve kitâbelerdir. Ayasofya-i Kebîr Cami-i Şerîfi ve manzumesinde bu manada birçok levha ve kitâbe yer almaktadır. Levha ve kitâbeler Arapça'dır. Az sayıda Osmanlıca Türkçesi ve Farsça metinler de bulunmaktadır. Dönemin hadislere ve Kur'ân-Sünnet bütünlüğüne yaklaşımı nasıldır? Sünnetin dindeki yeri açısından dönemle ilgili bazı bulgular elde edilebilir mi? Hat levhalarında yer alan metinlerin tercih sebepleri nedir? Hadis seçiminde sıhhat açısından hassasiyet gösterilmiş midir? Hz. Peygamber'e muhabbetin izleri bulunabilir mi? Çalışma bu sorulara cevap bulma çerçevesinde sürdürülecek hadise verilen değer ve sünnete i'tisamın boyutları anlaşılmaya çalışılacaktır. Doğrudan ya da dolaylı olarak hadislerle ilişkili metinler tespit edilecek, hadis metinlerinin sened ağları verilecektir. Levhalarda yer alan metinlerin; sünnete bağllık, Hz. Peygamber'e muhabbet, Kur'ân-Sünnet bütünlüğünü yansıtması ve teslîse karşı tevhîd vurgusu açılarından içerik analizi yapılacaktır.

Anahtar Kelimeler: Hadis, Ayasofya, Hat, Levha, Kitâbe.

\begin{abstract}
Hagia Sophia, one of symbols of Istanbul, was used as a church for 916 years, as a mosque for 481 years, and as a museum for 86 years, and was converted into a mosque in 2020. Which is considered a characteristic of some extensions have been made to Hagia Sophia, which was transformed into a mosque after the conquest of Istanbul by the Conqueror. An important element of these additions is calligraphy plates. What is the attitude towards Qur'ān-Sunnah integrity in that period? Was sensitivity shown in terms of authenticity while choosing the hadiths? Can any traces be found about the fondness to the Prophet? The study will be in the direction of finding answers the extents of the value attributed to hadiths and the commitment to Sunnah. The matns which are directly or indirectly related to the hadiths will be determined, their isnād hains will be provided, and the evaluations regarding the authenticity of the narrations will be given. The contents of the hadith texts on the plates will be evaluated in terms of their conformity with Sunnah, their love for the Prophet, reflecting the integrity of the Sunnah and the Quran and their emphasis on tawhid against Tathlıth.
\end{abstract}

Keywords: Hadīths, Hagia Sophia, Calligraphy, Plate, Inscription.

\section{Giriș}

Ayasofya, 916 yıl kilise, 481 yıl cami, 86 yıl da müze olarak kullanılmış ve 2020'de yeniden camiye dönüştürülmüştür. Büyük Kilise olarak bilinen bu yapı daha sonra Ayasofya adını almıştır. Fatih Sultan Mehmet, İstanbul'u fethedince Ayasofya'yı fethin sembolü olarak camiye çevirmiş ve hayratının ilk eseri olarak vakfetmiştir. Fetih sonrası özel ilgiye mazhar olan yapı, ilave donanımlarla yeni bir kimlik kazanmıștır. Tarihi süreçte tahrip olan eser, bir kısım değişiklikler ve bazı ek binalarla yeniden inşa edilmiștir. ${ }^{1}$ Fatih'in, yapının ve çevresinin harap görüntüsünü tasvir eden meşhur Farsça beyti tarihe kayıt düşme niteliğindedir.

1 Semavi Eyice, “Ayasofya”, Türkiye Diyanet Vakfi İslam Ansiklopedisi (İstanbul: Türkiye Diyanet Vakfı Yayınları, 1991), 4/446; Ahmet Akgündüz vd., Üç Devirde Bir Mâbed Ayasofya (İstanbul: Osmanlı Araştırmalı Vakfı Yayınları, 2005),100. 
"Perdedâri mîküned der kasr-ı Kayser ankebût

Bûm nevbet mîzened her kubbe-i Efrâsiyâa"z

Ayasofya Camii, dış ve iç mekânda ıslâh edici çalışmaların yanında hat levhaları ve kitâbelerle de tezyin edilmiştir. Amaç, sadece tezyinât değil, âyet ve hadisleri mimariye ortak etmek suretiyle esere ruh, sanata mana ve medeniyete ihtişâm katmaktır. ${ }^{3}$ Bu manada kitâbe ve levhalar, Ayasofya Camii ve müştemilâtında çokça yer almıştır. 1934 yılında müzeye dönüștürülen Ayasofya, 86 yıl sonra 10 Temmuz 2020 tarihinde Cumhurbaşkanı Recep Tayyip Erdoğan'ın kararı ile Diyanet İşleri Başkanlığı'na bağlanarak asli hüviyetine kavuşmuş ve kapısındaki Ayasofya Müzesi levhası sökülerek Ayasofya-i Kebir Cami-i Şerifi kitâbesi yerleștirilmiştir. ${ }^{4}$ Ardından Diyanet İşleri Başkanlığı tarafından Ekim 2020 tarihinde Ayasofya-i Kebir Cami-i Serifi Sempozyumu düzenlenmiștir. ${ }^{5}$ Öncesinde de Ayasofya Camii birçok akademik çalışmaya konu olmuştur. Akgündüz tarafından kaleme alınan $\ddot{U} \zeta$ Devirde Bir Mabed Ayasofya, kitabı konuyla ilgili değerli bilgiler barındırmaktadır. Bir başka çalışma da Yasemin Sönmez tarafından hazırlanmıştır. Sönmez, Ayasofya Külliyesi'nin Hat Levhaları ve Kitabeleri konulu araştırmasında konuyu sanat tarihi açısından incelemiştir. 6

Bu makalede ise Ayasofya'nın tanınmasına/tanıtılmasına katkı sunmak üzere Ayasofya-i Kebîr Cami-i Şerîfi hat levhaları ve kitabelerinde yer alan hadis metinleri analiz edilecektir. Levha ve kitâbelerin bazılarında doğrudan hadis metinlerinin yer aldığını, bazllarında yer alan metinlerde ise hadislerin etkili olduğu gözlenmektedir.

\section{Hadislerin Etkisi ile Oluşan Levha ve Kitâbeler}

Bu başlıkta; Kelime-i şehâdet, Kelime-i tevhîd, Besmele, İsm-i celâl, Esmâ-i hüsnâ, İsm-i nebî, Hülefâ-i raşidîn, Hasaneyn, Salât ü selâm ve Şefâat içerikli hatlar zikredilebilir.

\subsection{Kelime-i Şehâdet}

Şehâdet, İslâm binasının beş temel esasının ilk olup tasdik olunanın ikrarı anlamındaki "انهـ ان لا اله الا اله واثهذ ان محمدا عبده ورسوله cümlesidir. Kelime-i Şehâdet, Cami-i Şerîf'in mihrap sütunlarının sağ ve sol tarafında, hün-

Kayser'in kasrında örümcek perdedarlık ediyor, Efrasiyab’ın sarayında da baykuş nevbet çalıyordu Akgündüz vd., Üç Devirde Bir Mâbed Ayasofya, 128.

3 Bünyamin Erûl, "Çankırı Süleymaniye Camiinde Bulunan Kitâbeler Üzerine”, Uluslararası Anadolu'da Hadis Geleneği ve Dârü'l-Hadisler Sempozyumu, ed. Muhittin Düzenli (Samsun: Samsun Üniversitesi İlahiyat Fakültesi Yayınları, 2011), 399.

4 Türkiye Radyo Televizyonları Diyanet Televizyonu (TRT Diyanet TV), “Ayasofya Camii'ne 'Ayasofya-i Kebîr Cami-i Şerifi' tabelası asıldı" (Erişim 23 Haziran 2020).

5 Diyanet İşleri Başkanlığı (DİB), "Ayasofya-i Kebir Cami-i Şerifi Sempozyumu” (Erișim 29 Nisan 2021).

6 Yasemin Sönmez, Ayasofya Külliyesi’nin Hat Levhaları ve Kitabeleri (Konya: Selçuk Üniversitesi, Sosyal Bilimler Enstitüsü, Yüksek Lisans Tezi, 2018) 
kâr mahfili mihrabının sağ kısmındaki dehlizde ve kütüphane koridorunda ${ }^{7}$ olmak üzere üç ayrı yerde bulunmaktadır. Şehâdet kelimesinin Kütüb-i tis'a eserlerinde bazı farklılıklarla yaklaşık olarak 160 hadiste 12 ayrı cümle yapısıyla yer aldığı görülmektedir. Kelime-i Şehâdetle ilgili yapılan araştırma neticesinde Kütüb-i tis'a eserlerinde 60 kadar hadise ulaşılmaktadır. Şehâdet cümlesi, "Allah'a ve Rasûlüne iman ediniz." (en-Nisâ 4/136) ayetinin hadisle ifade edilmiş şeklidir. Kısmi bir hadis olarak Ayasofya hat levhaları ve kitâbelerinde yer aldığı anlaşılmaktadır.

\subsection{Kelime-i Tevhîd}

Kelime-i Tevhîd "لا اله الا اله محمد رسول الله" /"Allah'tan başka ilâh yoktur, Muhammed Allah'ı elçisidir, anlamında olup imanın, ulûhiyet ve nübüvvet olmak üzere iki esasını ifade eder. ${ }^{8}$ Tevhîd kelimesi; Caminin mihrap sofasında, minberin taç kısmında, hünkâr mahfilinin sağında, mihrap kısmında, kütüphanede, imârethâne girişinde ve III. Murat türbesinin kubbesinde olmak üzere dokuz ayrı mekânda yer almaktadır. ${ }^{9}$ Tevhîd kelimesinin ilk cümlesi, Kur'ân'ı Kerim'de 32 âyette Lâilâhe illallah, 1 âyette de Lâilâhe illâ ente şeklinde geçmektedir. Tevhîd'in ikinci cümlesi ise 1 âyette Muhammedün Rasûlüllâh 3 âyette de Muhammed ve Ahmed kelimeleri ile yer almaktadır.10 Kütüb-i tis'a'da yaptığımız tarama neticesinde Lâilâhe İllellâh ve Muhammedün Rasûlüllah ifadelerinin ayrı ayrı olmak üzere hadis metinlerinde çokça geçtiği görülmektedir. Bu sonuçlara göre, Kelime-i Tevhîd, bir hadis metni olarak da değerlendirilebilir.

\subsection{Besmele}

Besmele, genel olarak her hayırlı işe Allah'ın zikri ile başlama ve بسم اله اله "cümlesini irad etmedir.11 Ayasofya'da âyet, sûre, Esmâ-i hüsnâ bir de Arapça bir şiirle birlikte 16 ayrı yerde yazılı olan besmele, mihrapta, kitap deposu giriş kapısında ve sebilin sağ cephesindeki alınlıkta olmak üzere üç ayrı yerde müstakil olarak istiflenmiştir.12 Besmele cümlesinin âyet olarak değerlendirilmesi daha doğrudur. Fakat önemini izah eden hatırlatmalar açısından bakıldığında besmelenin, hadisle de irtibatlı olduğu açıktır. Kütüb-i tis'a'da yaptığımız bir taramada 80 civarında hadis karşımıza çıkmaktadır. Hz. Rasûl; "Yüce Allah'ı anarak başlanmayan her anlamlı söz veya iş, bereketsizdir/sonuçsuzdur."13 buyurmuştur. Birçok eylemde, örne-

Sönmez, Ayasofya Külliyesi'nin Hat Levhaları ve Kitabeleri , 24, 122.

Hatice Kelpetin Arpaguș, "Kelime-i Tevhîd", Türkiye Diyânet Vakfi İslam Ansiklopedisi (İstanbul: Türkiye Diyanet Vakfı Yayınları, 2002), 25/214.

Sönmez, “Ayasofya Külliyesi'nin Hat Levhaları ve Kitâbeleri”, 48-207.

el-Fetih 48/29; Âl-i İmrân 3/144.

Mehmet Görmez vd., Hadislerle İslâm (Ankara: Türkiye Diyanet Vakfı Yayınları, 2013), 1/77.

Sönmez, "Ayasofya Külliyesi'nin Hat Levhaları ve Kitâbeleri”, 20-231.

Ebû Abdullah Ahmed b. Muhammed b. Hanbel, Müsned, nşr. Şuayb el-Arnâûd-Âdil Mürşîd (Beyrût: Müessesetü'r-Risâle, 2001), 8712, 14/239. 
ğin yemeğe başlarken, ${ }^{14}$ eve girerken, ${ }^{15}$ kapıyı kaparken, ışığı kapatırken, yiyeceğin üzerini kapatırken, su kabının üzerini kapatırken ${ }^{16}$ cenâze kabre konulurken ${ }^{17}$ besmelenin zikredilmesi istenmiștir. Ayasofya'da yer alan besmelelerde âyetlerin yanında ilgili hadislerin de etkili olduğu söylenebilir.

\section{4. İsm-i Celâl, Esmâ-i Hüsnâ, İsm-i Nebi, Hülafâ-i Râşidîn, Hasaneyn}

İsm-i Celâl, "Varlığı zorunlu olan ve bütün övgülere lâyık bulunan zâtın öz adı, herhangi bir sözlük manası taşımayan Allah kelimesidir."18 Esmâ-i hüsnâ, ifadesi19 "esmâ/isimler" ile "hüsnâ/en güzel" anlamında iki kelimenin birleșmiş halidir. Muhammed, Hz. Peygamber'in (s.a.v.) isimlerinden biridir. Çocuğu dünyaya geldiğinde Âmine annemiz, Abdülmuttalib'e (öl. 577) bir haberci göndererek torununu müjdelemiş, Abdülmuttalib de torununa Muhammed ismini vermiștir. ${ }^{20}$ Hülafâ-i râșidîn, İslâm tarihinde Resûl-i Ekrem'den sonra iş başına gelen ilk dört kişi için yapılan isimlendirmedir. ${ }^{21}$ Hat yazılarında Hülafâ-i râş̧idîn öncelikli olarak yer almaktadır. Bu geleneğe Ayasofya'da da uyulduğu görülmektedir. Lafzâ-i celâl, İsm-i nebî, Çehâr-ı yâr-i güzîn ve Hasaneyn levhaları cami içinde; sütun başlarında, mihrap pencerelerinde, iç kubbe kemerlerinde, hünkâr kasrında, II. Selim türbesi kemerlerinde, türbenin kubbe pandiflerinde, III. Mehmet türbesinin kubbesinde, kütüphanede, şadırvan kubbesinin âleminde, III. Murat türbesinin tavanında ve kütüphane kubbesinde ${ }^{22}$ olmak üzere 9 ayrı mekânda yer almaktadır. Esmâ-i - hüsnâ, kütüphane okuma odasının duvarında, okuma odasının iç cepheye bakan pirinç bölümün alınlıklarında ve III. Mehmet türbesinin tavan kısmında ${ }^{23}$ olmak üzere üç ayrı yerde bulunmaktadır.

Dört büyük halife ile ilgili taltif içerikli çok sayıda hadis bulunmaktadır. Bununla birlikte "Herhangi bir ihtilâfla karşılaştı̆̆ınızda size düssen görev, benim sünnetime ve Hulefâ-i râşidîn'in sünnetine uymaktır." 24 hadisi de bu-

14 Ebû Îsa Muhammed b. îsâ et-Tirmizî, Sünen, nşr. Ahmed Muhammed Şâkir vd. (Mısır: Mektebetü ve Matbaatü Mustafa el-Bâyî el-Halebî, 1975), “Etime”, 47.

15 Ebû Dâvûd Süleyman b. Eșas es-Sicistânî, Sünen, nșr. Șuayb el-Arnâûd ( yy.: Dârü'r-Risâleti'l'Arabiyye, 2009), "Et'1me", 15.

16 Ebû Dâvûd, "Eșribe", 22.

17 İbn Mâce Ebû Abdullâh Muhammed b. Yezîd el-Kazvînî, Sünen, nşr. Şuayb el-Arnâûd (Beyrût: Dâru'r-Risâleti'l-Âlemiyye, 2009), "Cenâiz", 38.

18 Bekir Topaloğlu, "Allah”, Türkiye Diyânet Vakfi İslâm Ansiklopedisi (İstanbul: Türkiye Diyanet Vakfı Yayınları, 1989), 1/471.

19 el-Hașr 59/24.

20 Mustafa Fayda, "Muhammed", Türkiye Diyânet Vakfi İslam Ansiklopedisi (İstanbul: Türkiye Diyanet Vakfı Yayınları, 2005), 30/408.

21 Mustafa Fayda, "Hülâfâ-i Râşidîn", Türkiye Diyânet Vakfi İslam Ansiklopedisi (İstanbul: TDV Yayınlarl, 1998), 18/324.

22 Sönmez, “Ayasofya Külliyesi'nin Hat Levhaları ve Kitâbeleri”, 56-235.

23 Sönmez, "Ayasofya Külliyesi'nin Hat Levhaları ve Kitâbeleri”, 123-230.

24 Ebû Îsâ Muhammed b. Îsâ et-Tirmizî, Sünen, nșr. Beșșâr b. Avvâd (Beyrût: Dâru'l-Garbi'l-İslâmî, 1996), “ilim”, 16. 
lunmaktadır. Illk dört halifenin hadiste ișaret edilen rașid halifeler olduğuna dair kabul, Ebûbekir, Ömer, Osman ve Ali isimlerini ayrıca ehemmiyetli kılmıştır. Hat levhalarında bu isimlerin yer almasında hadislerin etkili olduğu aşikârdır. Müslümanlar arasında birlik ve beraberliği vurgulamak maksadıyla dört büyük halifenin isimlerine camilerde yer verilmiş olabilir.

Hasaneyn isimlendirmesi ile Hz. Peygamber'in torunları Hz. Hasan ve Hz. Hüseyin'in adlarının yazılı olduğu levhalar kastedilmektedir. Hasan ve Hüseyin isimlerine hat levhalarında yer verilmesi Peygamberimize ve onun ehl-i beytine olan sevginin bir tezahürüdür. Hz. Peygamber; Hz. Hasan ve Hz. Hüseyin'i, ehl-i beyt olarak tanımlamıs,, ${ }^{25}$ cennetin efendileri ${ }^{26}$ olarak vasıflandırmıș, her ikisi için "Allah'ım, ben onları seviyorum, sen de sev"27 diye duâ etmiștir. Allah Resûlü'nün torunlarına düşkünlüğünü ifade eden çok sayıda rivayet bulunmaktadır. Namaz esnasında sırtına çıktıklarında keyifleri bozulmasın diye secdeyi uzatmış,28 onları sırtında taşıdığı bir esnada "Ne güzel bir bineğe binmişsiniz" diyen bir sahâbîye "O da ne güzel süvaridir"29 sözüyle karşılık vermiştir. Bir kısmını aktardığımız bu haberler Hasan ve Hüseyin levhalarının hadislerle irtibatını göstermektedir.

Esmâ-i Hüsnâ ile ilgili olarak; Ebû Hüreyre, (öl. 58/78) Selmân-ı Fârisî, (öl. 36/656) Abdullah b. Abbas, (öl. 68/687-88) Abdullah b. Ömer (öl. 73/693) ve Hz. Ali'den (öl. 40/661) gelen rivayetler bulunmaktadır. ${ }^{30} \mathrm{Ha}-$ disin bazı farklılıklarla birçok tarikten temel hadis kaynaklarında yer aldığını görmekteyiz. ${ }^{31}$ Bu durumda Ayasofya-i Kebîr Cami-i Şerîfi'nde yer alan Esmâ-i Hüsnâ hatlarının hadislerden beslendiğini söylemek mümkündür.

\subsection{Salâtüselâm}

Sözlükte 'dua, t'azim ve rahmet olarak açıklanan salât ile güven manasindaki selâm sözcüklerinden meydana gelen salâtüselâm ile Aleyhi's-salâtü ve's-selâm, Sallallâhü aleyhi ve sellem ve benzeri terkipler kastedilmektedir. Salâtüselâm okuma ve salavat getirme olarak bilinir. Salvele şeklinde de isimlendirilir. ${ }^{32}$ Ayasofya hat levhaları ve kitâbelerinde salâtüselâm ile ilgili metinler yer almaktadır. Mihrapta celi sülüs hatla yazılı besmelenin, bir kısmı sağında bir kısmı da solunda olmak üzere; "Allah ve melekler pey-

25 Tirmizî, "Menâkıb", 31.

26 Tirmizî, "Menâkıb", 30; Ebû Bekr b. Ebî Șeybe Abdullah b. Muhammed b. İbrâhim b. Osman, elKitâbü'l-musannef fi'l-ehâdîsi ve'l-âsâr, nşr. Kemâl Yusuf el-Hût (Riyâd: el-Mektebü'r-Rüşd, 1983), $6 / 378$.

27 Buhârî, Ebû Abdullâh Muhammed b. İsmâîl, el-Câmiu'l-müsnedi's-sahîhu'l-Buhârî̀, İstanbul: Çağrı Yayınları 1981), "Libâs", 58.

28 Ebû Abdurrahman b. Şuayb en-Nesâî, Sünenü, nşr. Abdü'l-Fettah Ebû Gudde (Halep: Mektebetü'lmetbûâti'l-İslâmiyye, 1986), "iftitâh", 83; Hâkim, Ebû Muhammed b. Abdullah en-Neysâbûrî, Müstedrek ale's-sahîhayn, (yy.: Dârü't-Tesîl, 2014) 2/197.

29 Tirmizî, "Menâkıb", 31.

30 Tirmizî, "Deavât", 82

31 İbn Mâce, "Du'â"”, 10.

32 M. Suat Mertoğlu, "Salâtüselâm", Türkiye Diyânet Vakfı İslam Ansiklopedisi (İstanbul: Türkiye Diyanet Vakfi Yayınları, 2018), 36/23. 
gambere salât ediyorlar; ey iman edenler, siz de ona salât ve selâm okuyun"33 âyeti yer almaktadır. ${ }^{34} \mathrm{~Hz}$. Peygamber'e ve onun âline salât okunması talebinin de yer aldığı Şeyh Sa'dî Şîrâzî'nin (öl. 691/1292) şiirinden alınmış "Cemali ile karanlıkları aydınlattı; O'na ve ailesine selam eyleyin" levhası yer almaktadır. Kütüphanenin dış cephe giriş bölümündeki pirinç alınlıkları üzerinde, sonunda salâtüselâmın da yer aldığı Peygamber Aleyhi's-Selâm'ın bazı vasıflarının yazıldığı bir kitâbe bulunmaktadır. ${ }^{35}$

Camide yer alan salâtüselam vurgularının konu kapsamındaki hadislerle bağlantılı olduğunu düşünmek gerekir. Kaynaklarda salâtüselâmı teşvik eden çok sayıda hadis yer almaktadır. ${ }^{36}$ Abdullah b. Mes'ûd'dan (öl. 32/652-53) rivayet edildiğine göre, Resûlullah şöyle buyurmuştur: "Kıyamet günü insanların bana en yakını, bana en çok salavât getirendir." ${ }^{\prime 37}$ Ali b. Ebû Tâlib'in (öl. 40) naklettiğine göre de Resûlullah şöyle buyurmuștur: "Cimri, yanında anıldığım hâlde bana salavât getirmeyen kimsedir." ${ }^{\prime 38}$ Dolayısıyla salâtüselâm içerikli tabloların hadislerle de ilişkilendirilmesi mümkündür.

\section{6. Şefâat}

"Sözlükte tek olanı çift hale getirmek; birinin önüne düşüp işini görmeye çalışmak, işinin görülmesi için birinin aracılığını istemek manasına gelir."39 Dünyada şefâat; sâlih kişilerden dünyalık bir gereksinimin yerine getirilmesi yahut kusurların affedilmesi için dua talebinde bulunmak olarak açılanmıștır. ${ }^{40}$

Şefâat ile ilgili olarak Ayasofya-i Kebîr Cami-i Şerîfi'nde mihrap sofasının sol tarafında41 "Allah'ım Muhammed aleyhi's-aelâm'ın şefaatiyle cennetine bizleri de kabul eyle" yazısı yer almaktadır. Kütüphanenin koridorunda duaların kabulü için "peygamberlerin efendisi hürmetine" şeklinde bir tevessül cümlesi bulunmaktadır. Şadırvanda Sultan Mahmut'un (öl. 1199/1785) vasıflarının anlatıldığı şiirin bir mısraında "Peygamberin emrine amadedir." ifadesi ile Hz. Peygamber'e olan itaat vurgulanmak suretiyle affına bir vesile cümlesi olarak nakședildiği söylenebilir. Hz. Peygamber'in ahiret haya-

el-Ahzâb 35/56.

Sönmez, “Ayasofya Külliyesi'nin Hat Levhaları ve Kitâbeleri”, 39, 40.

“Allah! kulun Mustafa, Nebîn Münteka, Habibin Murtaza, Resûl'ün Müctebâ, Ebu'l-Kasım seyyidimiz Muhammed ve onun tüm sahabîlerinden razı olsun. Allah'ım, kendisi ile mahlûkatı mutlu kıldığın ve ahlakıyla kullarını bezediğin Nebîne salat ve selam eyle." Sönmez, "Ayasofya Külliyesi'nin Hat Levhaları ve Kitâbeleri." 119.

36 Buhârî, "Deavât", 32; Ebu'l-Hüseyin b. el-Haccâc el-Kuşeyrî en-Nisâbûrî, Sahîhu Müslim, nşr. Halîl, Memûn Șeyhâ (Lübnan: Dâru'l-Marife, 2005), "Salât”, 65.

37 Tirmizî, "Vitr", 21.

38 Tirmizî, "Deavât", 100.

39 Mustafa Alıcı, "Şefâat", Türkiye Diyânet Vakfi İslâm Ansiklopedisi (İstanbul: Türkiye Diyanet Vakfı Yayınları, 2010), 38/411.

40 Yusuf Şevki Yavuz, "Şefâat”, Türkiye Diyânet Vakfi İslam Ansiklopedisi (İstanbul: Türkiye Diyanet Vakfı Yayınları, 2010), 38/412.

41 Sönmez, “Ayasofya Külliyesi'nin Hat Levhaları ve Kitâbeleri”, 42. 
tında müminlerin affına vesile olması anlamında çok sayıda hadiste șefâat konusu vurgulanmaktadır. ${ }^{42}$ İlgili hadislerden Müslim'de yer alan bir rivâyette Resûlullah şöyle buyurmuștur: "Her peygamberin niyaz ettiği bir duası vardır. Ben de duamı kıyamet gününde ümmetime şefâat etmek için saklamak istiyorum." ${ }^{\prime 3}$ Ayasofya'da şefâat içerikli hatların hadislerden beslenen metinler olduğu söylenebilir.

\section{Hadis Metinlerinden Oluşan Hat Levhaları ve Kitabeler}

Ayasofya-i Kebîr Cami-i Șerîfi ve müştemilatında doğrudan hadis metinlerinden oluşan levha ve kitâbeler bulunmaktadır. Çalışmamızın ana kısmını da bu levha ve metinler oluşturmaktadır. "Hikmetin başı Allah korkusudur." "Kim bir mescit inșa ederse Allah da ona cennette bir kössk inșa eder." "Cennet annelerin ayakları altındadır." "İstanbul mutlaka fetholunacaktır. Onu fetheden ordu ne güzel ordu onu fetheden komutan ne güzel komutandir." "Allah'ım senden dünyada ve ahirette af ve afiyet istiyorum." "Allah'ım sen affedicisin, affi seversin beni affeyle." "Sübhânallahi ve bi-hamdihi, subhanallahi'l-azîm." "Namaz kılan kişi, Rabbi ile baş başa konuşmaktadır." Hat levhalarında yer alan bu hadislerin bir kısmı tamamen bir kısmı da kısaltılarak levha ve kitâbelerde yer bulmaktadır. Çalıșmanın bu kısmında hadis metinleri Kütüb-i tis`a eserleri kapsamında analiz edilecek, Kütüb-i tis'a mecmuasında rastlanamazsa bu durumda diğer kaynaklarda taranacaktır.

\section{1. "Hikmetin Başı Allah Korkusudur" Hadisi}

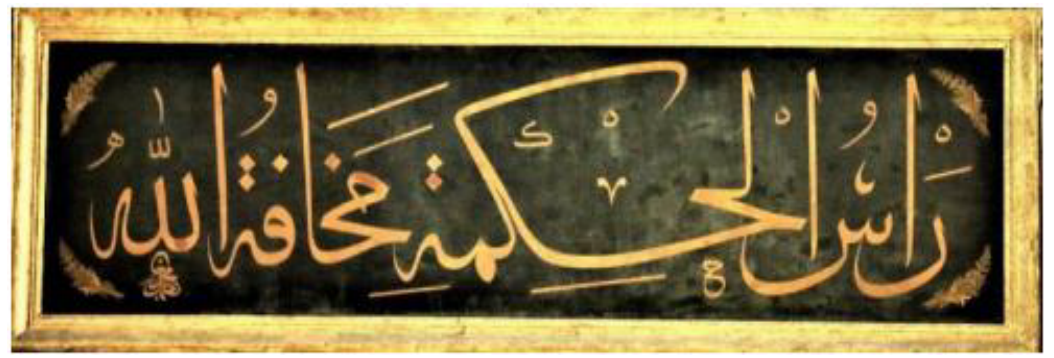

Sultan III. Ahmed'e ait bir hat olduğu belirtilen levha mihrap sofasının sağ tarafında yer almaktadır. ${ }^{44}$ Kütüb-i sitte'de bir örneğine rastlamadığımız metin; Musannef-i ibn ebî Şeybe, ez-Zühd lî ebî Dâvûd, Kitâbü'l-emsâl fîehâdîsi'n-ebevî, Bahru'l-fevâid, el-Medhal ile's-eüneni'l-kübrâ, Şuabu'l-îmân, Câmiu's-sağîr ve el-Muhît fî-ehâdîsi'n-nebeviyye isimli hadis eserlerinde mevkûf ve merfu olarak nakledilmektedir. Levhada hadisin bir kısmı yer

\footnotetext{
Buhârî, "Rikāk", 51.

Müslim, "Îmân", 334.

Sönmez, "Ayasofya Külliyesi'nin Hat Levhaları ve Kitâbeleri”, 44.
} 
almaktadır. Bu kısım, ilgili kaynakların tamamında aynı lafızlarla olarak geçmektedir.45

Hadis, hem merfû bir hadis hem de İbn. Mes'ûd ve Ukbe b. Âmir'in sözü, (öl. 32/652-53) şeklinde mevkûf olarak rivâyet edilmiştir. Irakî, (öl. 806/1404) hadisin yer aldığı kaynaklara işaret etmiş ardından da zayıf hükmünü vermiştir.46 İbn Hacer, (öl. 852/1449) cümlenin farklı bir lafızla "أن رأس الحكمة خشية الرب عز وجل" zebûr'da yer alan bir metin olduğunu beyan etmiștir. ${ }^{47}$ Beyhâkî, (öl. 458/1066) hadisin mevkûf olduğunu, merfu rivayetinin zayıf olduğunu ifade etmektedir. ${ }^{48}$ Hadisin sened ağı şema halinde Şekil-1' de gösterilmiştir.

\section{Şekil 1: Hadisin Sened Ă̆}
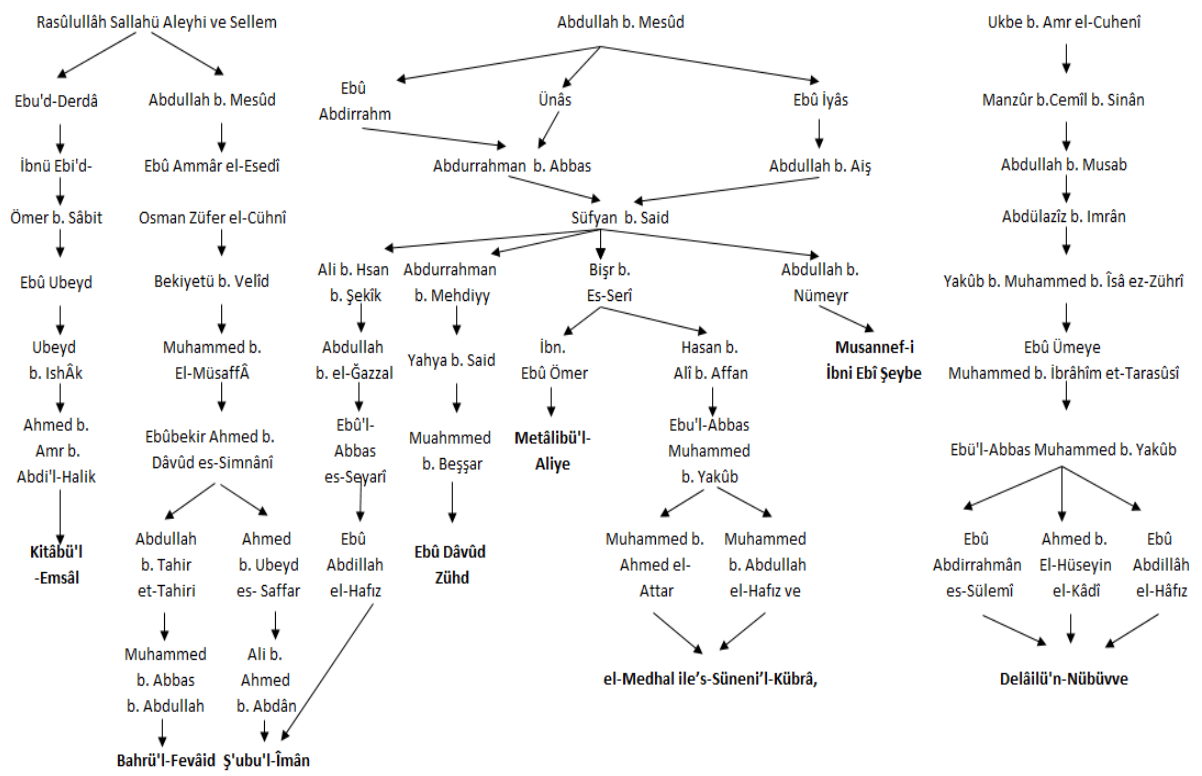

45 Ahmed b. Hüseyin b. Alî b. Mûsâ el-Hüsrevcirdî el-Horasanî Ebûbekîr el-Beyhakî, Delâilü'n-nübüvve, nşr. Abdulmutî (yy.: Dârü'l-Kitâbi'l-İlmiyye, 1988), 5/241; Ebû Şeybe, el-Musannef fi'l-ehâdîs ve'lâsâr, 7/107, 8/162; 19/169; 19/336; Abdullah b. Muhammed b. Cafer, Kitâbü'l-Emsâl fí-Ehâdîsi'nNebevî, 1/294; Ebûbekir Muhammed b. İbrahim b. Yakûb el-Kelebâzî, Bahrü'l-fevâid, nşr. Vecihi Kemalettin Zekî (Kāhire: Darü's-Selâm, 2008), 1/105, 275; Ahmed b. El-Hüseyin b. Ali b. Mûsa elBeyhâkî, el-Medhal ile's-Süneni'l-Kübrâ (Kuveyt: Dârü'l-Hülefâ, tsz.), 1/426; Ahmed b. El-Hüseyin b. Ali b. Mûsâ Ebûbekir el-Beyhâkî, Şuabü'l-îmân nşr. Abdü'l-Alî Abdü'l-Hamîd (Bombay: Mektebetü'rRüșd, 2003), 2/201, 202; Subhî Mahmûd Amire, el-Muhît fí- ehâdisi'n-nebeviyye ve'l-asar ve's-aünen (Misır: Dirâsetü'l-İslâmiyye, tsz.), 5/166.

46 Ebû'l-Fadl Zeynü'd-Dîn Abdurrahman b. el-Hüseyin b. Abdurrahman el-Irakî, el-Muğnî an hamli'lesfâr fi'l-esfâr fí tahrîci mâ fíll-ihyâi mine'l-ehbâr (Beyrut: Dâru İbn Hüzeyme, 2005), 8/330.

47 Ebu'l-Fadl Ahmed b. Ali b. Muhammed b. Ahmed b. Hacer el-Askalanî, el-Metâlibü'l-âliye bi-zevâidi'lmesânidi's-semâniye, nșr. Said b. Nadır b. Abdü’l-Azîz (Daru'l-Asıme, 1998), 94.

48 Beyhâkî, Şuabu'l-Îmân, 2/201. 1/470; Ebul Hasan Ali b. Muhammed b Muhammed b. Habîb el-Basrî, el-Emsâl ve'l-hikem, nşr. Fuad Abdülmünim (Riyâd: Dârü'l-Vatan, 1999), 1/234. 
Levhada yer alan kısım Hz. Peygamber'in Tebük seferi esnasında yaptığı bir konuşmada sayılan emir ve tavsiyelerden birisidir. Hadis metni ile "... Allahtan ancak âlimler korkar..."49 âyeti arasında bir ilişki kurulabilir. Allah'tan korkmak, onun büyüklüğü karșısında duyulan heyecan ve O'na hakkıyla kul olamama endişesini taşımaktır. Bu endişeyi taşıyanlar ve ona göre hayatlarına yön verenler için "...Allah onlardan razı olmuş, onlar da Allah'tan razı olmuşlardır. İște bu, Rabbini sayıp O'ndan korkanlar içindir." ${ }^{50}$ buyurulmaktadır. "Kur'ân-ı Kerîm'in bu bağlamda bilmenin değerine vurgu yapması oldukça ilginçtir. Fakat burada kullanılan ve bilenler/ulema kelimesinin bir şeyi derinlemesine tanıyıp mahiyetini idrak etme ve bir konuda kesin bilgiye ulaşma, manalarının bulunduğu göz önüne alınırsa, Allah'a saygı duyma hususunda ön plana çıkarılan kişilerin, birtakım bilgileri öğrenip belleklerine yerleștirmiş olanları değil, zihnî çabalarını Allah'ın evrendeki kudret delillerinden sonuçlar çıkarabilme düzeyine yükseltebilmiş kişiler olduğu anlaşılır."

"Hikmetin başı Allah korkusudur" hadisi ile Allah'ın yüceliğini, kâinattaki eşsiz sanatını ve kudretini tanımanın ve onun karşısında ürperen bir idrake ulaşmanın esas olduğu vurgulanmıștır. Aksi halde Hz. Peygamber'in “...Allah'ım! Huşû duymayan kalpten, fayda vermeyen ilimden... sana sı̆̆ınırım"52 uyarısına konu olma haliyle Allah Rasûlünün sakındırdığı olumsuzluklara maruz kalma durumu baş gösterebilir. Bu açıdan bakıldığında sened itibari ile hasen olduğu belirtilen hadis metninin, içeriği itibari ile de âyet ve hadislerle teyit edildiğini görmekteyiz. Hadîsin, merfu rivâyetinin zayıf olduğunda ittifak edildiği, mevkûf rivayetini zayıf görenlerle birlikte hasen li gayrihî olarak değerlendirildiği de anlaşılmaktadır. Zayıf olduğu belirtilen bir rivâyetin, ileri derecede zayıf olmamak kaydıyla başka zayıf rivâyetlerle desteklenmesi durumunda hasen li gayrihî mertebesine ulaşacağı belirtilmektedir. ${ }^{53}$ Ayrıca zayı $f$ hükmü verilmiş bir hadis, asla sahîh değildir anlamına da gelmez. Sahih denilen bir hadisin zaylf olma ihtimali olduğu gibi zayı $f$ denilen bir hadisin de sahih olması muhtemeldir. ${ }^{54}$ Haberin farklı tariklerden destekleniyor olması, mevkûf tarikleri hasen li gayrihî olarak değerlendiren muhaddislerin varlığı, Allah'tan ancak âlimler korkar âyeti ile de teyit edilmesi Hikmetin başı Allah korkusudur rivayetini hasen derecesinde makbul bir hadis olduğu kanaatini oluşturmaktadır.

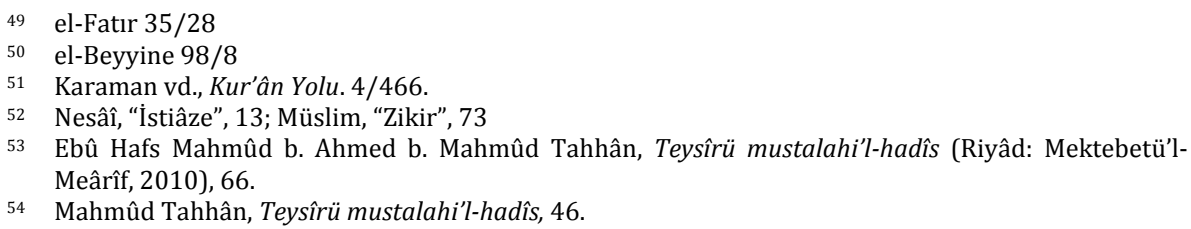




\subsection{Allah'a Sevimli Gelen İki Kelime; "Sübhânallahi ve bi-hamdihi, subhanallahi'l-azîm lafızları"}

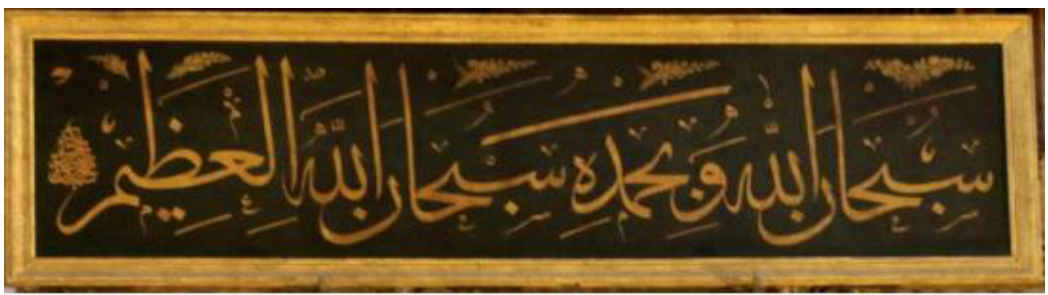

Sultan II. Mahmut'a ait olan bu levha, mihrap sofasının sağ tarafında bulunmaktadır. ${ }^{55}$ Hadisin baş kısmında bulunan "Rahmân'a sevimli, mizanda ağır dile hafif iki kelime vardır" kısmı levhada yer almamıștır. Hadis-i Şerifin tam metni; "Dilde hafif, mizanda ă̆ır, Allah'a sevimli olan iki kelime vardır. Bunlar: Sübhânallahi ve bi-hamdihi, subhanallahi'l-azîmdir" ş̧eklindedir. كلمتان خفيفتان على اللسان، ثقيلتان في الميزان، حبييتان إلى Hadis, Sahih-i Buhârî́dde lafızları ile geçmektedir.

Müslim, Tirmizî' ve Ahmed b. Hanbel'in eserlerinde ${ }^{57}$ yer alan metin, bu metinle birebir aynıdır. Buhârî'de tevhîd babında tekrar edilen rivâyet, bazı takdim tehirlerle değiş̧iklik göstermektedir. ${ }^{58}$ Hadisin sened ağı Şekil-2'de verildiği gibidir.

Şekil 2: Hadisin Sened Ağı

Rasûlullâh Sallhü Aleyhi ve Sellem

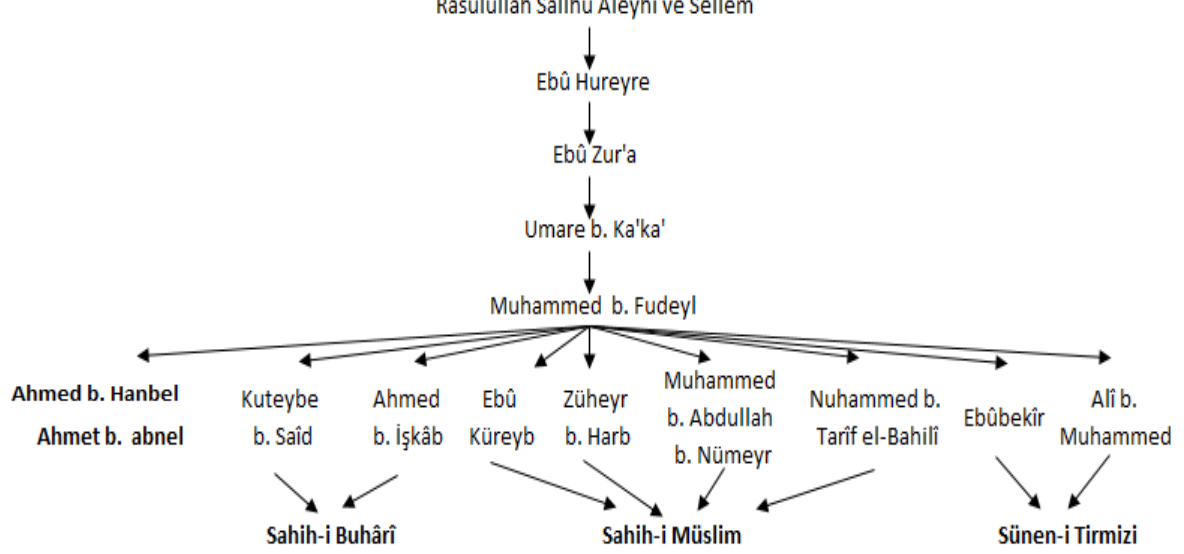

Şekilde de görüldüğg̈ üzere hadisin, Kütüb-i-tis'a içerisinde Ahmed $b$. Hanbel'de 1, Buhârî'de 2, Müslim'de 4 ve Tirmizi'de 2 olmak üzere toplamda 9 tariki bulunmaktadır. Tabloya göre hadisi Muhammed b. Fudayl'dan do-

\footnotetext{
Sönmez, “Ayasofya Külliyesi'nin Hat Levhaları ve Kitâbeleri”, 46.

Buhârî, "Îman", 19.

Müslim, “Zikir”, 8; Tirmizî, “Edep”, 56; Ahmed b. Hanbel, Müsned, 12/86, 716.

58 Buhârî, "Tevhîd", 58.
} 
kuz râvi aktarmıştır. Buhârî, Müslim ve İbn Mâce, eserlerine aldıkları hadisi farklı hocalardan rivayet etmişlerdir. Müttefekun aleyh ${ }^{59}$ bir hadis olduğu görülmektedir.

\section{3. “Mescit Yaptırana Cennette Köşk Verilir” Hadisi}

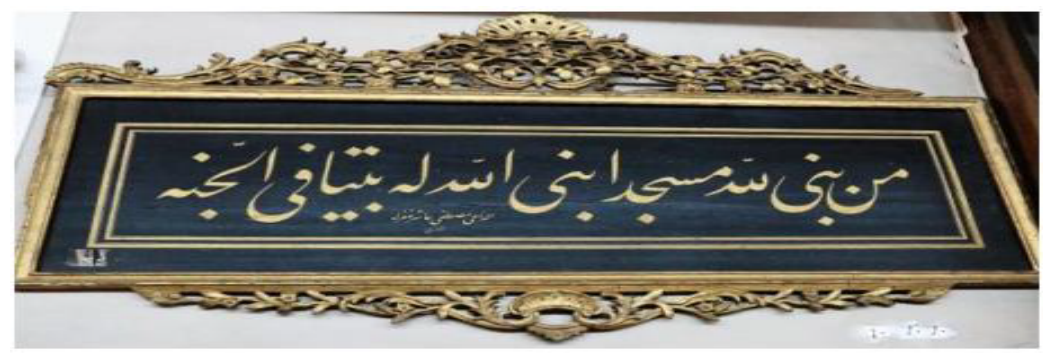

Mustafa Aşir'e (öl. 1804) ait olduğu tespit edilen levhanın, depoda olduğu belirtilmektedir.60 Türkçe'ye "Kim, Allah rızâsı için bir mescit yaparsa, Allah da ona cennette bir ev yapar" şeklinde tercüme edilir. Hadisin sened şeması Şekil-3'te gösterilmiştir.

Şekil 3: Hadisin Sened Ağı

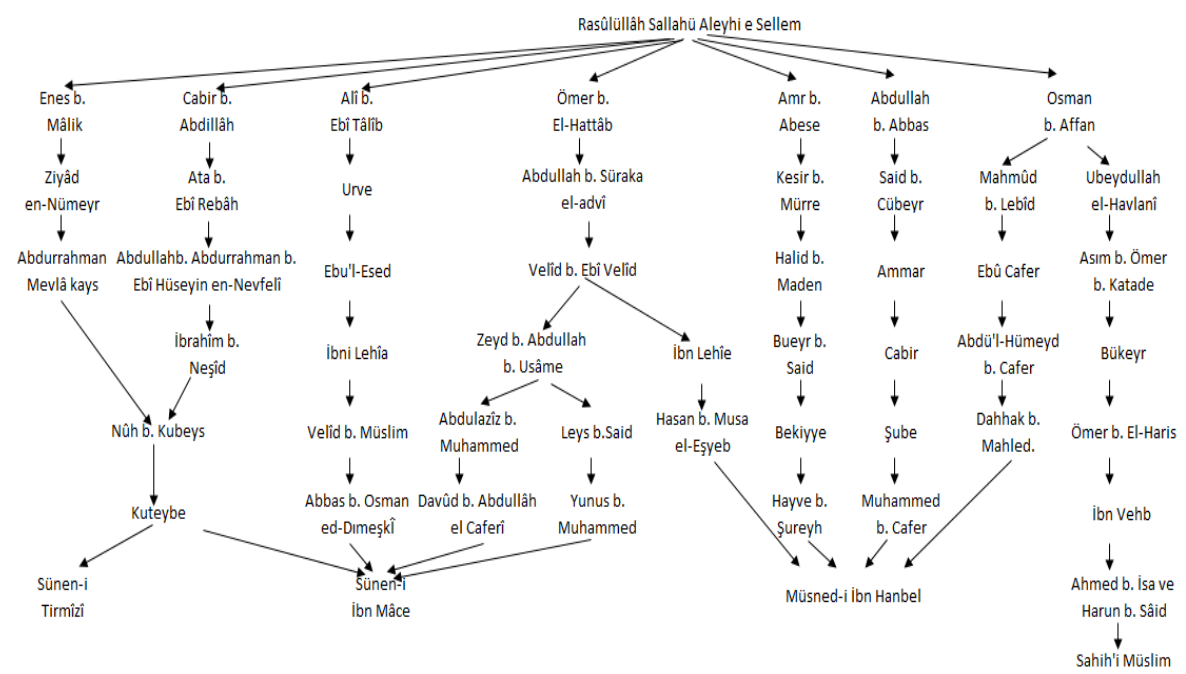

Hadisin 10 ayrı tarikten bize ulaştığı görülmektedir. Metinler, manayı

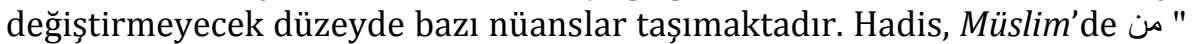
"بنى مسجدا ـ قال بكير: حسبت أنه قال - يبتغي به وجه الله، بنى الله له مثله في الجنة

59 Buhârî ve Müslîm'in her ikisinin de rivâyet ettiği hadislere denir. Subhî İbrahîm es-Sâlîh, Ulûmu'lhadîs ve mustalahuhû (Beyrut: Dâru'l-İlmi'l-Melâyîn, 1984), 1/118.

60 Sönmez, “Ayasofya Külliyesi’nin Hat Levhaları ve Kitâbeleri”, 77. 
hemen bir sonraki rivâyette de "مثله" yerine "بيتا" kelimesi61 ile geçmektedir.

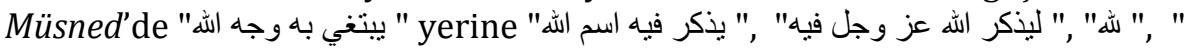
"farklılıkları ile beş ayrı rivâyeti yer almakta-

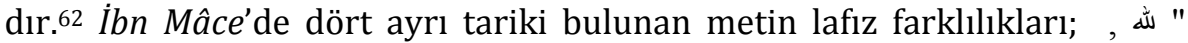

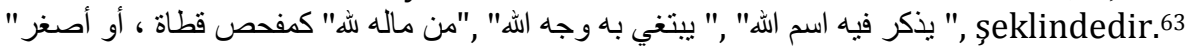
İbn Mâce'de yer alan metinlerden birisi Müslim rivâyeti ile birisi de Ahmed b. Hanbel rivâyeti ile birebir aynıdır. Tirmizî de yer alan metin de صغير اكان " صل "lafzı iledir.64 Şekilden de anlaşılacağı üzere hadisi Tirmizi, İbn Mâce, İbn Hanbel ve Müslim tahriç etmiștir.

\section{4. "Cennet Annelerin Ayakları Altındadır" Hadisi}

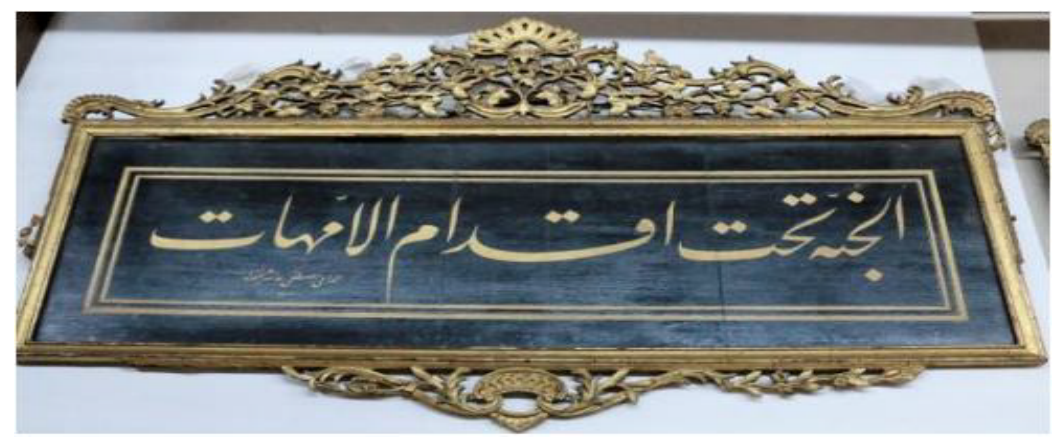

Mustafa Aşir Efendi'ye ait olduğu bilinen tablonun depoya kaldırıldığı belirtilmektedir.65 Hadis, "الجنة تحت أقدام الأمهات" lafızları ile yalnızca Müsned-i

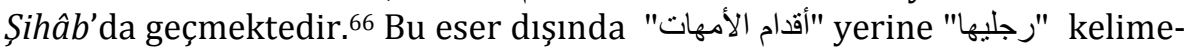

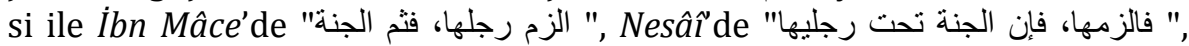

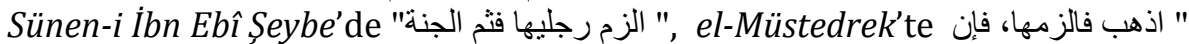

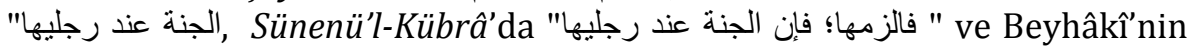

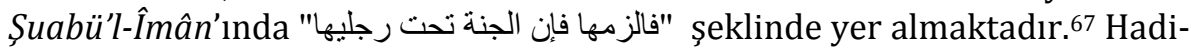
sin senetleri Şekil-4'de verilmiştir. Sened şemasından da anlaşılacağı üzere metnin, tespit edebildiğimiz kadarıyla Sünen-i İbn Mâce'de 3, Sünen-i Nesâ̂i de 1, Sünen-i Beyhâkîdde 1, Şuabu'l-îmân 'da 1 Musannef-i ibn ebî Şeybe'de 1 Müsned-i Şihâb'da 1 ve el-Müstedrek'de 2 olmak üzere 8 ayrı tarikten bize ulaştığı görülmektedir. Hadisin Sened ağı Şekil-4'de verilmiştir.

\footnotetext{
Müslim, "Mesacit", 3.

Ahmed b. Hanbel, Müsned, 1/442 (376), 4/54 (2157), 32/187 (19440).

İbn Mâce "Mesâcîd", 1/4.

Tirmizî, "Salat", 120.

Sönmez, "Ayasofya Külliyesi'nin Hat Levhaları ve Kitâbeleri”, 77.

6 Ebû Abdullah Muhammed b. Selâme b Cafer b. Ali el-Kuddâî el Misrî, Müsnedü’ş-Şihâb, nşr. Hamdi b. Abdulmecit es-Selefî (Beyrut: Müessesetü'r-Risâle, 1986), 102.

67 İbn Mâce, "Cihâd", 12; Nesâî, Cihâd, 6; İbn Ebî Şeybe, Musannef, 6/518; Hâkim, Müstedrek, 3/338, 7/276; Ahmed b. El-Hüseyin b. Ali b. Mûsâ Ebûbekir el-Beyhâkî, es-Sünenü'l-kübra, nşr. Muhammed Abdü'l-Kādir Atâ (Beyrût: Dârü'l-Kitâbi'l-İlmiyye, 2003), 9/45; Beyhâkî, Şuabu'l-îmân, 10/248.
} 
Şekil 4: Hadisin Sened Ağı

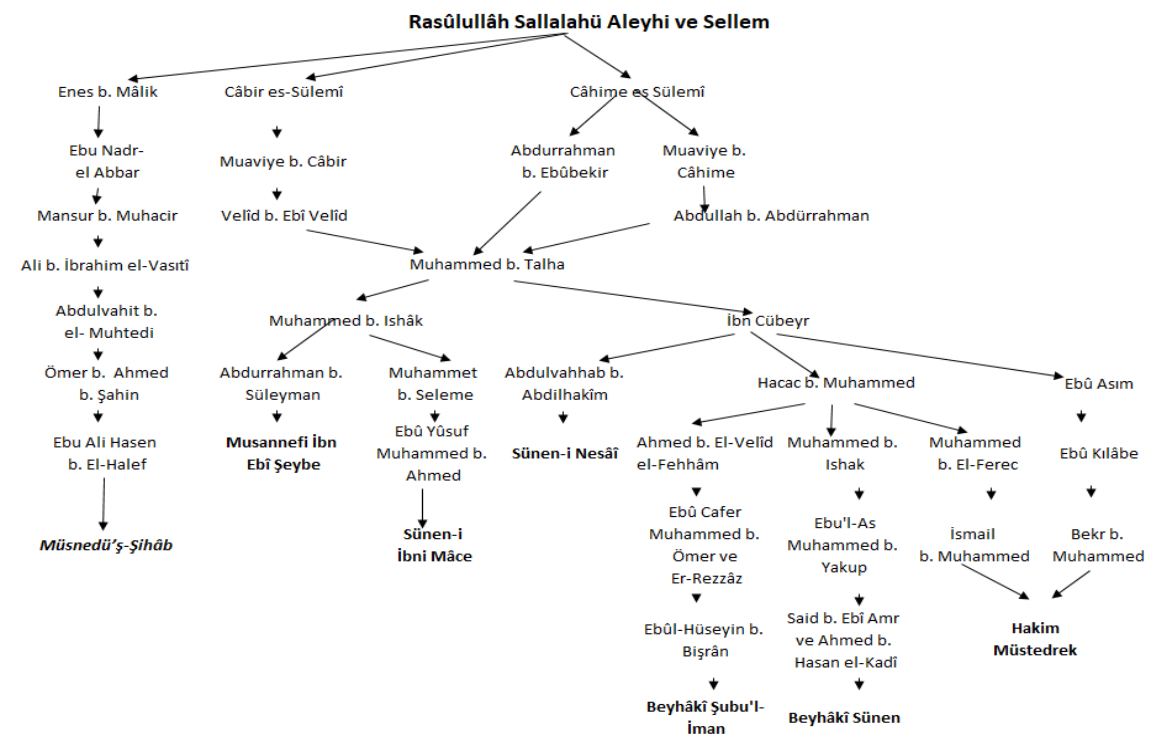

Aclûnî, (öl. 1162/1749) bu hadisin "الامهات "lafzıyla rivayetinin zaylf olduğunu belirtmektedir. ${ }^{68}$ Kanaatimizce bu kullanım mana ile rivâyet kapsamında düşünülebilir. "رجليها" ifadesinin doğru anlaşllabilmesi için hadisin vürûd sebebi ile birlikte nakledilmesi icâb etmektedir. Vürûd sebebine göre Hz. Peygamber'e gelen sahabî, Allah'ın rızasına/cennetine ulaşmayı arzu ederek cihada iștirak etmek istediğini belirtir. Hz. Peygamber de ona "Annen sağ $\mathrm{ml}$ ?" diye sorar, "Evet" cevabını alınca "O halde git annene hizmet et. "Cennet onun ayakları altındadır" buyurur. Hadiste vurgulanan "Cennet, annenin ayakları altındadır," düşüncesidir. Bu anne de sadece muhatap olan sahâbî ile sınırlı olmayacağına göre maksat, "Cennet annelerin ayakları altındadır." cümlesi ile bütün anneleri kapsayacak şekilde ifade edilmiştir. Sebeb-i vürudu zikredilmeden doğru anlamayı sağlamak ancak bu cümle ile mümkündür. Bu sebeple hadisin sahih kabul edilen lafzı yerine zayıf kabul edilen lafzı tercih edilmiş olmalıdır. Her iki lafızda da mana ortak olduğundan ve mana ile rivâyetinde caiz olduğundan hareketle zayıf olduğu düşünülen rivâyetin, sahih kabul edilen rivayetlerle desteklendiğini dolayısıyla hasen li-gayrihî derecesine yükseldiği kanaati oluşmaktadır. 


\subsection{Müjde Hadisi}

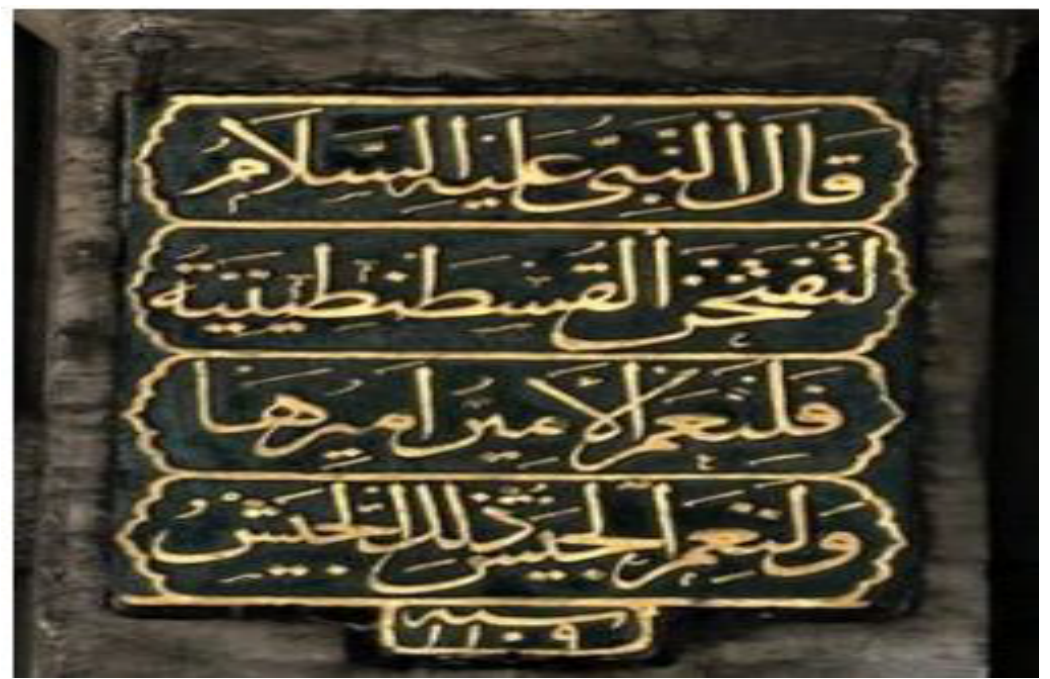

Hadis, bir kitâbe olarak caminin dışında yer almaktadır. II. Mustafa döneminde camiye yerleştirildiği belirtilen kitâbenin kim tarafından yazıldığı bilinmemektedir.69 Bişr el-Ğanemî’den nakledildiğine göre Hz. Peygamber şöyle buyurmuştur: "İstanbul mutlaka fetholunacaktır O'nu fetheden komutan ne güzel komutan onu fetheden asker ne güzel askerdir." Metni bize ulaştıran tarikler Şekil-5'te verilmiştir.

Şekil 5: Hadisin Sened Ağ̀

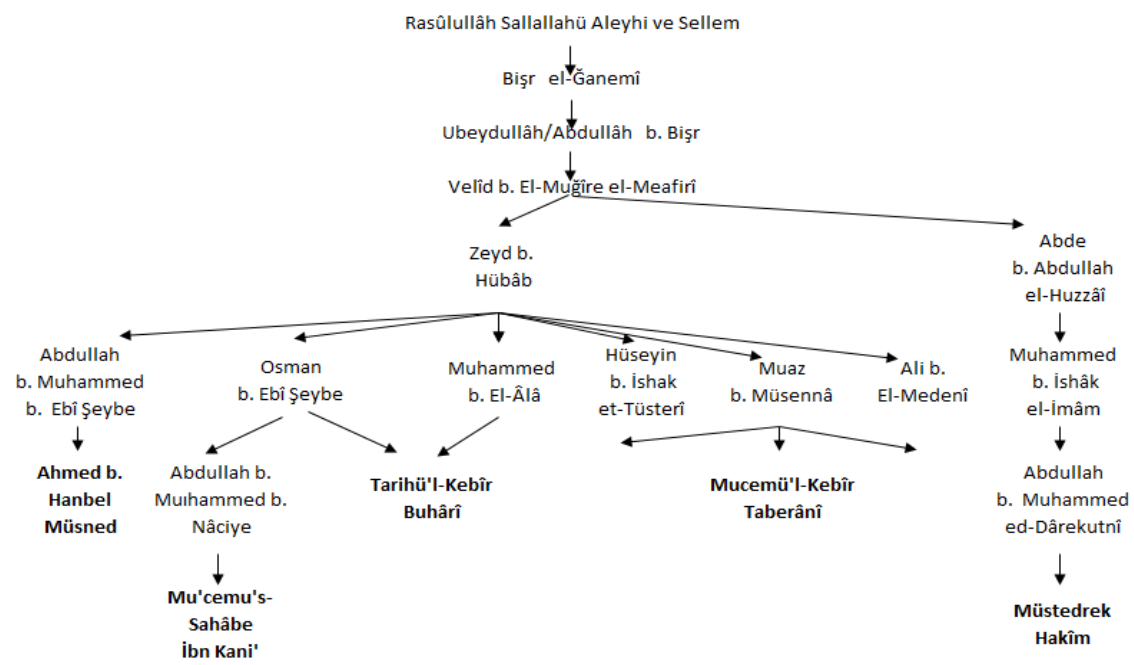

69 Sönmez, "Ayasofya Külliyesi'nin Hat Levhaları ve Kitâbeleri”, 85. 
Tespit edebildiğimiz kadarıyla beş ayrı kaynakta rastladığımız metin; et-Târîhü'l-Kebîr, el-Müstedrek, Mu'cemü'l-Kebîr ve Müsned'de تلفتحن"

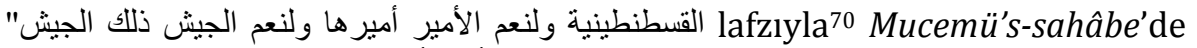

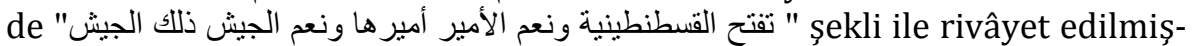
tir. ${ }^{71}$ Şekil-5'te de görüldüğü üzere Hadisin; Mucemü's-Sahâbe'de 1, etTarîhü'l-Kebîr'de 2, Ahmed b. Hanbel'in Müsned'inde 1, el-Mucemü'l-Kebîr'de 3 ve el-Müstedrek'de 1 olmak üzere 8 ayrı tariki bulunmaktadır. Ayrıca İbn Abdü'l-Berr (öl. 463/1071) ve İbnü'l-Esîr72 ( öl. 630/1233) sahâbî biyografilerini ele aldıkları eserlerinde hadisin sahâbî ravisi, Bişr el-Ğanemî'den bahsederken hadis metnine de yer vermişlerdir. ${ }^{73}$

Müsned'de yer alan rivayetle ilgili olarak Muhakkik, zayıf olduğu kanaatindedir. ${ }^{74}$ Hâkim en-Neysabûrî, ${ }^{75}$ (öl. 405/1014) hadise 'sahih' hükmünü vermiş ayrıca el-Câmiü's-Sağîr' in șerhlerinde de hadisin aynı şekilde sahih olduğu vurgulanmıștır. ${ }^{76}$

Ali Kulat tarafından hazırlanan bir makalede hadis; merfu, senedi muttasıl, râvileri birbirleriyle mülâki ve sika olarak değerlendirilmiștir. Sahâbeden itibaren geniş kitleler arasında meşhur olmanın yanında, insanların bu haberin tahakkukuna şahitlik etmek uğruna canlarını vermiş olmaları, hadisin sıhhatinin delili olarak gösterilmiştir. ${ }^{77}$ Ayrıca Elbânî (öl. 1999) ve Ebû Reyye'nin(öl. 1970) hadisi zayıf olarak değerlendirmelerine de değinilmiştir. İstanbul'un Türkler tarafından fethedilmesi ardından gündeme taşındığından ve fetih öncesinde de aleyhte bir yorum yapılmadığından hareketle Elbânî ve Ebû Reyye'nin değerlendirmeleri isabetli görülmemiştir. ${ }^{78}$

Hadis üzerine bir makale de Ali Yardım tarafından hazırlanmıştır: Yardım, makalesinde; ravileri ayrı ayrı incelemiş senedinin muttasıl, ricalinin

70 Ebû Abdillâh Muhammed Buhârî, Tahrîcü'l-ehâdîsi'l-merfati'l-müsnedeti fî kitâbi't-tarihi'l-kebîri li'lBuhâri, nşr. Muhammed b. Abdülkerim b. Ubeyd (Riyâd: Mektebetü'r-Rüșd, 1999) 1/791; Ebû Abdullâh el-Hâkim Muhammed b. Muhammed en-Neysâbûrî, nşr. Mustafa Abdü'l-Kādir Atâ, Müstedrek ale's-sahihayn, (Beyrût: Dârü'l-Kitâbi'l-İlmiyye, 1990) 4/468; Süleyman b. Ahmed, etTaberânî, el-Mucemü'l-kebîr, nşr. Hamdi b. Abdü'l-Mecîd es-Selefî (Kāhire: Mektebetü İbn Teymiye, 1994) 2/38; Ahmed b. Hanbel, Müsned, 31/287 (18957).

71 Ebu'l-Hüseyin Abdülbakî b. Kāni b. Merzûk b. Vâsık el-Emevî, nşr. Salih b. Sâlim, Mucemü's-sahâbe, (Medine: Mektebetü'l-Ğürebâ, 1418), 1/81.

72 Ebü'l-Hasen Alî b. Ebi'l-Kerem Muhammed b. Muhammed İzzüddîn İbnü’l-Esîr, Üstü'l-gābe fímarifeti's-sahâbe (Beyrût: Dârü'l-Fikir, 1989), 1/224.

73 Ebû Ömer Yûsuf b. Abdullâh b. Muhammed b. Abdü’l-Berr en-Nemrî, nşr. Muhammed el-Becâvi, ellstiab fi ma'rifeti'l ashab, (Beyrût: Dârü'l-Ceyl, 1992), 1/170.

74 Ahmed b. Hanbel, Müsned, 31/187 (18957).

75 Hâkim, Müstedrek ale's-Sahihâyn, 4/468.

76 Muhammed b. İsmâîl b. Salâh b. Muhammed el-Hasenî, et-Tenvîr șerhü Câmiü's-sağîr, nşr. Muhammed İshâk (Riyâd: Mektebetü Dârü's-Selâm, 2011), 9/30; Zeynüddîn Muhammed el-Medâv Ali b. Zeynülabidîn, et-Teysîr bi-şrh-i Câmii's-sağîr (Riyâd: Mektebetü'l-İmâmü'ş-Șafiî, 1988), 2/290.

77 Ali Kulat, "İstanbul'un Fethini Müjdeleyen Hadisin Değerlendirmesi”, Diyanet İlmi Dergi, $37 / 2$ (Aralık 2001), 20.

78 Kulat, “İstanbul'un Fethini Müjdeleyen Hadisin Değerlendirmesi”18, 19. 
âdil ve zâbıt, rivayetlerine itimad edilir ve tümüyle mevsuk olduklarını ifade ile hadisin sahih olduğunu beyan etmiştir. ${ }^{79}$

Fetih hadisi ile ilgili çalışma yapanlardan bir diğer araştırmacı İsmail Lütfü Çakan'dır: Çakan, Hâkim ve Zehebî'nin 'sahih' değerlendirmelerini, hadisin erken dönem eserlerinde yer almasını, sened zincirinin büyük oranda ortak olmasını, hadis diye uydurulmuş sözler konusunda kitap yazan hiçbir müellifin fetih hadisi için "uydurmadır" dememesini ve İstanbul'un fethi ile ilişkili başka hadislerin de mevcut olmasını ${ }^{80}$ ileri sürerek hadisin sahih olduğunu belirtmiştir. Çakan, hadisin aleyhinde değerlendirmelerde bulunan Ebû Reyye, Nâsıruddîn Elbânî ve Müsteşrik Marius Konar'ın, indî, tarafgir, gayri ciddî ve keyfî yorumlarla konuya yaklaștığını belirtmektedir. 81

\section{6. "Dünyada ve Ahirette Af ve Mağfiret İsteme” Hadisi}

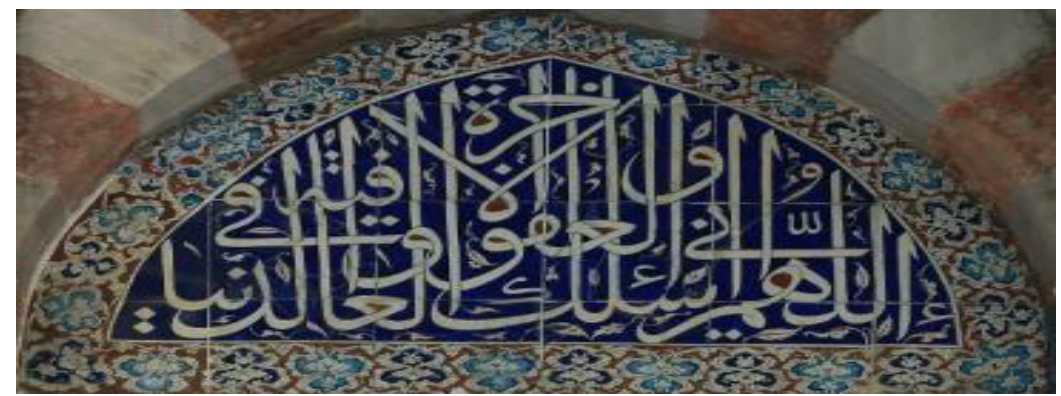

“...Allah'ım senden af, dünya ve ahirette afiyet isterim...” Kitâbe, III. Murat türbesinin giriş kapısının solunda yer almaktadır. ${ }^{82}$ Ebû Dâvûd'da geçtiği şekliyle metnin tamamı şu şekildedir. Cübeyr b. Ebî Süleyman b. Cübeyr b. Mutım'den İbn Ömer'in şöyle dediğini rivâyet etmiştir: Ben İbn Ömer'i şöyle derken işittim: "Rasûlullah (s.a.) akşam ve sabah vakitlerine eriştiği zaman şu duaları okumayı asla terk etmezdi: Allahım, senden dünya ve âhirette afiyet dilerim. Allahım! Senden dinim, dünyam, aile fertlerim ve maIım hakkında afv ve afiyet dilerim, Allah'ım ayıbımı ört, korkularımdan emin kıl, Allahım beni önümden, arkamdan, sağımdan solumdan ve üstümden (gelecek her türlü tehlikeden) koru. Altımdan (gelecek belalarla) helak olmaktan senin büyüklügüne sığınırım." 83 Hadisin metni Kütüb-i-tis'a eserlerinden Müsned-i Ahmed b. Hanbel, Sünen-i ibn Mâce, Edebü'l-müfred, Sünen-i Ebû Dâvûd, Müsned-i Humeydî, Sahîh-i ibn Hıbbân ve Sünen-i Nesâ̂i'de geçmektedir. Hadisin sened ağı Șekil-6'da verilmiştir.

79 Ali Yardım, "Fetih Hadisi Üzerine Bir Araștırma”, Diyanet İlmi Dergi, 13/2 (Haziran 1997), 119.

80 Buhârî, "Cihâd", 3, 178 "Tabirü'r-rüyâ" 12; Müslim, "Fiten", 95, "Îmâre”, 16; Ebû Dâvûd, "Cihâd", 9.

81 İsmail Lutfî Çakan, "Fatih Hadisi ve Akşemseddîn'in Fetihteki Yeri”, Akșemseddin Sempozyumu (Ankara: Akşemseddin Vakfı Yayınları, 1991), 155-157.

82 Sönmez, "Ayasofya Külliyesi'nin Hat Levhaları ve Kitâbeleri”, 209.

83 Ebû Dâvûd, "Edeb", 100 
Şekil 6: Hadisin Sened Ağı

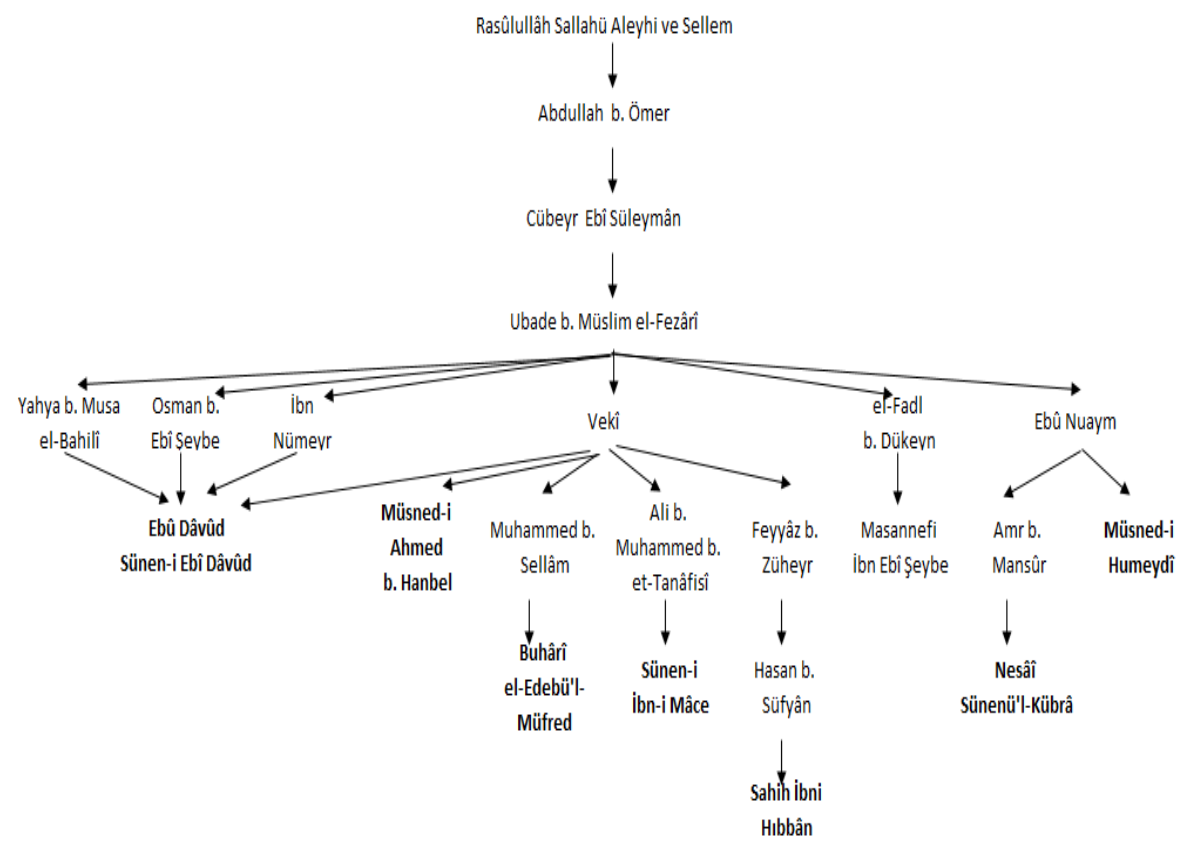

Hadis, Kütüb-i-tis'a dişından da araştırılmıştır. Metinler içerik olarak birbirine yakındır. Kitâbede yer alan cümle bütün hadislerde mevcut olup iki cümlenin birleştirilmiş halidir. "......... cüm-

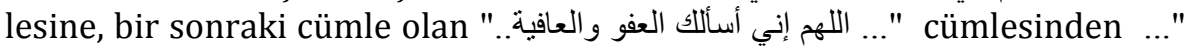
cümlesi oluşturulmuş ve bu şekilde yazilmıştır.

Metinde 'ihtisâr' yapıldığını söylemek daha isabetli olacaktır. Tabloda yer alan cümle tespit edebildiğimiz kaynakların tamamında ${ }^{84}$ hadis metninin " اللهم إني أسألك العافية في الدنيا والآخرة، اللهم إني أسألك العفو و العافية kismindan klsaltılarak șekillendirilmiş bir cümledir Hadisin; Sünen-i Ebû Dâvûd, Müsnedi Ahmed b. Hanbel, Edebü'l-Müfred, Sünen-i İbn Mâce, Sahîh-i İbn Hıbbân, Musannef-i İbn Ebî Şeybe, Sünen-i Nesâ̂i ve Müsned-i Humeydî̀ de olmak üzere 10 ayrı tarikini görmekteyiz. Hadislerin 5 tanesi Kütüb-i-tis'a'da, 5 tanesi de diğer kaynaklarda yer almaktadır.

84 İbn Mâce, "Dua”, 5; Ahmed b. Hanbel, Müsned, 8/403 (4785); İbn Ebî Șeybe, Musannef, 6/35; Ebû Abdullâh Muhammed b. İsmail Buhârî, el-Edebü'l-müfred (Riyâd: Mektebetü'l-Meârîf, 1998), 681; İbn Balabân, Ebu'l-Hasan Alâeddin Ali b. Abdullah, el-İhsan fi takrîb-i sahîh-i ibn Hıbbân nșr. Şuayb el-Arnaûd (Beyrut: Müessesetü'r-Risâle, 1988), 3/241; Ebû Muhammed Abdülhamid b. Humeyd b. Nasr el-Kessî, el-Müntehâb min müsnedi $a b d$ b. Humeyd, nşr. Mustafa el-Advî (Endülüs: Dâru Belensiye, 2002), 2/53 


\section{7. “Allah'ım Sen Affedicisin Affı Seversin Beni Affet" Hadisi}

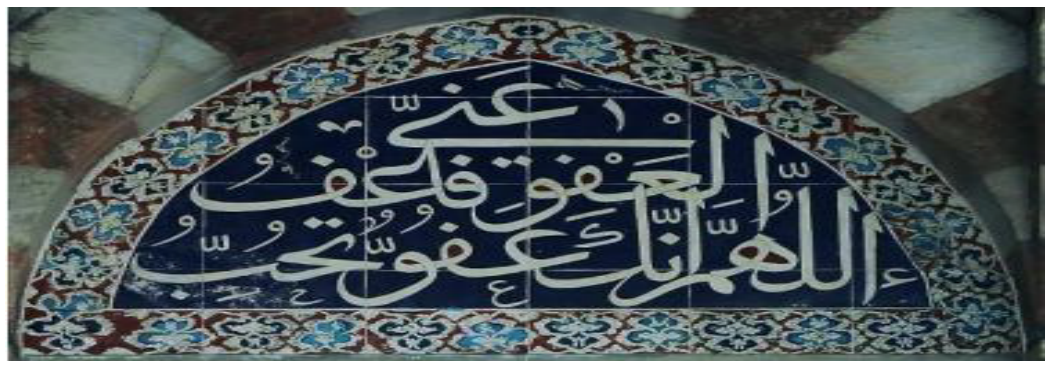

Kitâbe III. Murat Türbesi'nin giriş kapısının sağında yer almaktadır. ${ }^{85}$ Vürûd sebebine göre, Hz. Aișe validemiz, Hz. Peygamber'e (s.a.v.) Kadir Gecesi'ne ulaşırsam nasıl dua deyim?' diye sormuş, bunun üzerine bu dua kendisine öğretilmiștir. Hadisin Sende ağı şekil 7'de verilmiştir.

Şekil 7: Hadisin Sened Ağı

Rasûlullâh Sallallahü Aleyhi ve Sellem

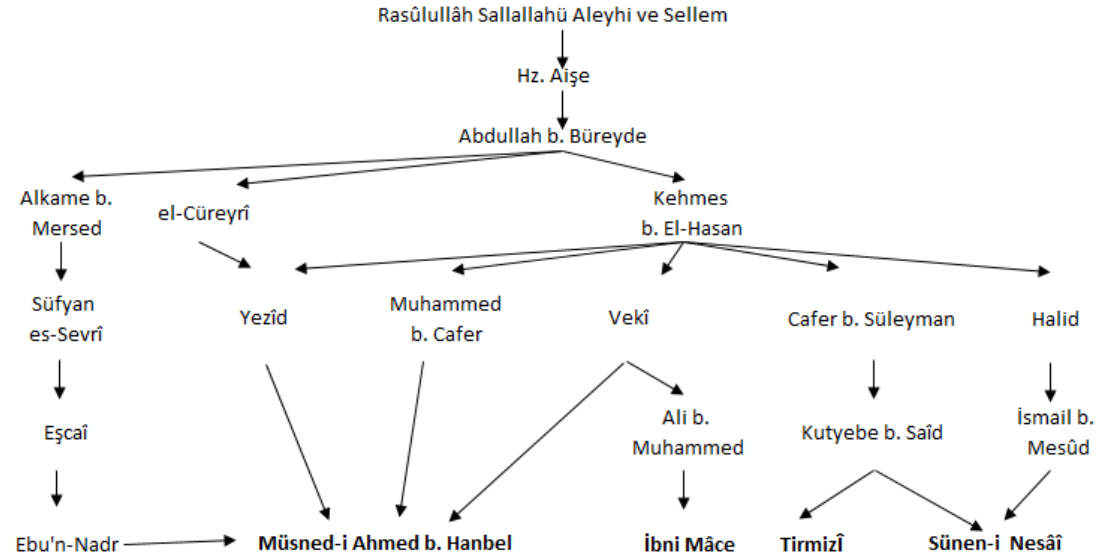

Kütüb-i tis'a içerisinde 8 ayrı tarikini tespit edebildiğimiz hadisin metni, ilgili eserlerin tamamında " اللهم إنك عفو تحب العفو ، فاعف عني lafzıyla rivâyet edilmiştir.86 Sadece vürûd sebebi ifade edilirken bazı farklılıklara rastlanmaktadır. Bazı tariklerde; "إن و افقت ليلة القدرما أقول" "Kadir gecesinde bulunursan ne diyeyim?”; "إن و افقت ليلة القدر ، فبم أدع" "Kadir gecesinde bulunursan

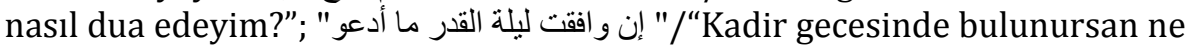

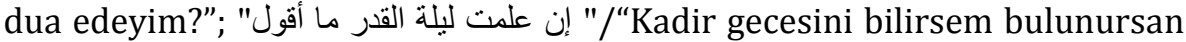
ne diyeyim?"; "إن علمت أي ليلة ليلة القدر، ما أقول فيها أليها "/"Kadir gecesinin hangi gece olduğunu bilirsem o gecede ne diyeyim?" şeklinde farklılıklar bulunmaktadır. Şekilde de görüldüğü üzere hadis, Ahmed b. Hanbel'de 4, İbn Mâce'de

85 Sönmez, “Ayasofya Külliyesi'nin Hat Levhaları ve Kitâbeleri”, 209.

86 Tirmizî, "Duâ", 83; İbn Mâce, "Dua”, 5; Nesâî, "Nuût”, 37; Ahmed b. Hanbel, Müsned, 42/236 (25384), 316 (25495), 317 (25497), 484 (25741). 
1, Tirmizi'de 2 ve Nesâî'de 2 olmak üzere Kütüb-i tis'a eserleri içerisinde 9 ayrı tarikten bize ulaştığı anlaşılmaktadır. ${ }^{87}$

\subsection{Namaz Kılan Kişi Rabbi İle Konuşmaktadır}

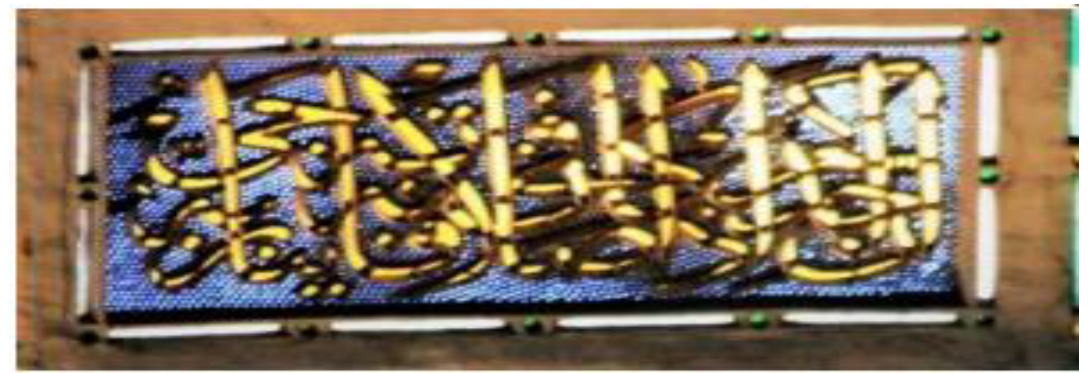

Hadîs, Ayasofya-i Kebîr Cami-i Şerîfi'nde mihrap duvarlarının alt sırasındaki revzenlerde ${ }^{88}$ yazılmıştır. ${ }^{89}$ Kitâbede yer alan hadis, Kütüb-i-tis' $a$ eserleri içerisinde Buhârî, Müslim ve Ahmed b. Hanbel'de geçmektedir. Hadisin sened ağ

Şekil 8: Hadisin Sened Ağı

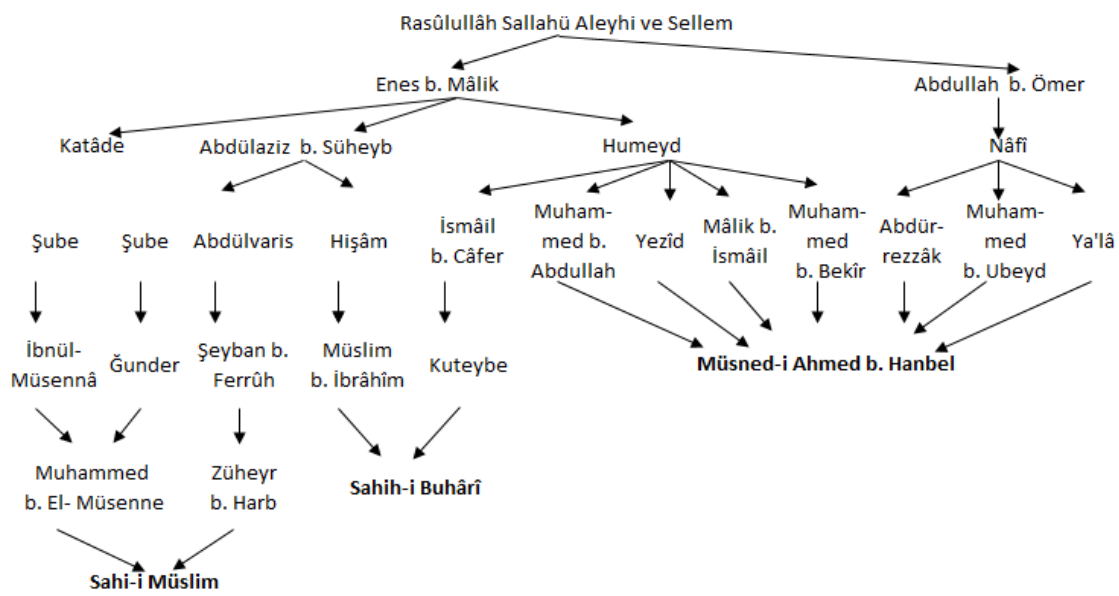

Hadisin vürûd sebebine göre, mescidin kıble yönünde duvar üzerinde tükürük izi gören Hz. Peygamber bu davranışı nehyeden uyarılarda ve önerilerde bulunmuş ve namazın önemini hatırlatan bu cümlenin de yer aldığı bir hadisi irad buyurmuștur. Hadis Kütüb-i-tis'a eserlerinden İbn Hanbel'de 7, Müslim'de 3 ve Buhârî̀de 2 ayrı senedle yer almaktadır.

87 Ahmed b. Hanbel, Müsned, 42/236, 316, 317; İbn Mâce, “Duâ”, 5; Tirmizî, “Duâ", 91.

88 Farsça pencere anlamındadır. Abdullah Yeğin, Osmanlıca Türkçe ansiklopedik büyük lûgat (İstanbul: Türdav, 1990), 829.

89 Sönmez, “Ayasofya Külliyesi’nin Hat Levhaları ve Kitâbeleri”, 108. 


\section{Hat Levhaları ve Kitâbelerin Değerlendirilmesi}

Estetik açıdan mekânlarımızın iç ve dış tezyininde önemli bir unsur olan cami içerisindeki levha ve kitâbeler, 1453'ten itibaren yaklaşık beş asrı içine alan dönemin, sanat anlayışını, duygu dünyasını, düşünce ufkunu, hadîse vukûfiyetini ve sünnete riâyetini gösteren belgelerdir. Ayasofya-i Kebîr Cami-i Şerîfi'nde yer alan hat levhaları da şekil ve içerik yönüyle derin anlamları muhtevidir. Sanat değeri açısından yetkin kişiler tarafından, farklı çalışmalar yapılmış, hat ve tehzîb değeri üzerinde durulmuştur. Ayasofya-i Kebîr Cami-i Şerîfi külliyesi levha ve kitâbelerinde yer alan hadis metinlerinin tercih edilmesinde fethin, tevhîdin, muhabbetullah ve muhabbet-i Rasûlillâh'ın etkili olduğunu düşünülmekte, bu yönlerden ele alınmasında fayda mülahaza edilmektedir.

\section{1. Âyet ve Hadis Bütünlüğ̈}

Levhâ ve kitâbelerde âyet ve hadis birlikteliğinin yer aldığı müşahede edilmektedir. Besmele, Kelime-i şehâdet, Kelime-i tevhîd, İsm-i celâl, İsm-i nebî Hulefâ- raşidîn ve Hasaneyn hatlarının mevcudiyeti âyet-hadis birlikteliğinin güzel bir örneğidir.

Âyetlerin hadislerle iç içe olması Kur'ân-sünnet bütünlügünün bir yansımasıdır. Mihrap duvarında alt orta pencerelerin birinde "قال لله تعالى hemen yakınındaki diğer pencerede "قال رسول اله 'ifadesi yer almaktadır. Bir pencerede "Artık Allah'a secde edin ve kul olun!"90 âyeti yer alırken bir diğer pencerede âyetin açıklaması mahiyetinde secdenin ve kulluğun namazla gerçekleşeceğini vurgulayan "Namaz kılan kişi Rabbi ile konuşmaktadır" hadisi yer almaktadır. Bir levhada "Allah'ın mescitlerini ancak Allah'a ve âhiret gününe inanan kimse imar eder..."91 âyetine; bir diğer levhada "Kim Allah için bir mescit inşa ederse Allah da ona cennette bir ev inşa eder" hadisine yer verilmektedir.

Metinler arasında Hz. Nebînnin tebliğ, tebyin, tezkiye ve hikmeti öğretme görevlerinin vurgulandığı Cuma sûresi 2. âyetin ve Hz. Peygamber'e itaat etmeyi emreden âyetlerden Nisâ sûresi 59. âyetin ${ }^{92}$ yer alması Kur'ânSünnet bütünlüğünü ortaya koyan bir başka örnektir. Kütüphanede yapılan tasnifte kitap bölümleri isimlendirmelerinde hadis kitaplarının bir bölüm oluşturacak kadar yekûn tutması ve bu bölüme Hadis-i Şerîf Kitapları isimlendirmesinin yapılması özellikle şerîf ifadesi sünnete olan hürmeti göstermektedir. Verilen örnekler, ilgili dönemlerin Kur'ân-sünnet bütünlüğüne olan hassasiyetinin izleri olarak değerlendirilebilir.

\footnotetext{
Necm 53/62.

Sönmez, “Ayasofya Külliyesi'nin Hat Levhaları ve Kitâbeleri”, 192.

Sönmez, "Ayasofya Külliyesi'nin Hat Levhaları ve Kitâbeleri”, 239.
} 


\subsection{Peygamber Sevgisi}

Mabedde hadis metinlerine yer verilmesi Efendimize muhabbetin bir nişanesi olarak düşünülmelidir. Hz. Peygamber'e Resûl ve Nebi olarak yapılan atıflar dışında bizzat Muhammed isminin toplamda 20 defa mekânın farklı yerlerine nakședilmesi Efendimize olan muhabbetin önemli bir ifadesi olarak değerlendirilmelidir.

"Allah ve melekler peygambere salât ediyorlar; ey iman edenler, siz de ona salât ve selâm okuyun." "93 âyeti ile Salâtüselâm hatırlatılmıștır. Sa'dî Şîrâzî'ye (öl. 691/1292) ait olduğu belirtilen "Cemali ile karanlıkları aydınlattı; O'na ve ailesine selam eyleyin." mısraı ve Kasîde-i Bürde yazılmıștır. Salâtüselâm telkini ile biten ve Peygamberimizin bazı vasıflarının yer aldığı bir metin mevcuttur. Bu tercihlere Hz. Nebî̀ye olan bağlılığın bir göstergesi olarak bakılmalıdır.

Tablo ve kitâbeler incelendiğinde görülecektir ki Muhammed, Resûl, Nebî kelimelerinin geçtiği yerlerde yazmanın zorluğuna ve alanın darlığına rağmen Sallallahü aleyhi ve sellem ifadesinin yazılması ihmal edilmemiștir. Günümüzde çoğu kere (s.a.s.) kısaltmasıyla geçiștirilirken hacmi küçük bir tabloda yahut bir revzenin daracık alanında dahi Salâtüselâm mutlaka nakşedilmiştir. Bu tercihler Muhabbet-i Rasûlillâh olarak görülmelidir.

“Allah'ım, Muhammed Aleyhi's-selâm'ın șefaati ile cennete bizleri kabul eyle" levhasının, "Peygamberlerin efendisi hürmetine" șeklinde bir tevessül cümlesinin ve bir şiirde Sultan Mahmûd'un meziyeti olarak "Peygamberin emrine râm bir dâver-i pür cûddur" cümlesinin, hatlarda yer bulmasının sebebi peygamber sevgisinde aranmalıdır.

\subsection{Tevhîd Vurgusu}

Tevhîd, " Allah'ın zâtında, sıfatlarında ve fiillerinde yegâne olduğunu benimsemektir." ${ }^{4} \mathrm{~Hz}$. Âdem' Aleyhi's-Selâm'dan, itibaren dinler, temelde tevhîd akidesine sahipken süreç içerisinde farklı mecralara kaymalar olmuştur.

Şirkin mekânı haline getirilen Mescîd-i Haram, Mekke'nin fethi ile birlikte aslî hüviyetine kavușturulduğu gibi, Ayasofya'nın da fethin sembolü olarak teslisten tevhîde yani aslî hüviyetine dönüștürüldüğü söylenebilir. Bu sebeple Ayasofya'da yer alan hatlara konu edinilen metinlerde tevhîd vurgusu dikkat çekmektedir.

Tevhîd ve şehâdet kelimelerinde Allah'ın varlığı ve birliğine olan inanç ilân edilir, O'nun dışındaki ilah anlayışları örneğin teslîs reddedilmiş olur. Hz. Peygamber'in kul ve resûl olduğu inancı açıklanırken aynı zamanda

93 Ahzâb 33/56.

94 Mevlüt Özler, “Tevhid”, Türkiye Diyânet Vakfı İslam Ansiklopedisi, İslam Ansiklopedisi (İstanbul: TDV Yayınları, 2012), 20-21. 
peygamberin kul ve resûl olmaktan başka vasıfla vasıflanamayacağı dolayısıyla Hz. İsâ'ya yüklenilen ulûhiyet anlayışının batıl olduğu ortaya konulmaktadır. ${ }^{95}$ Buradan hareketle yazılarda Hz. Peygamber'e çokça yer verilmesinde ve şehadet cümlelerinin tekrar tekrar yazılmasında tevhîd inanclnı vurgulama isteğinin etkisi olmalıdır. Aynı şekilde besmelenin ve İsm-i celâlin çokça zikredilmesi, tevhîd vurgusunun bir yansıması olmalıdır.

Hat levhaları ve kitâbelerde Allah'ı vasfeden âyetlerin tercih edildiği gözlenmektedir. "Allah göklerin ve yerin nûrudur.", "O, evveldir ve ahirdir, zahirdir ve bâtındır...", "Allah ki, O'ndan başka ilâh yoktur. Hayy'dır Kayyum'dur...", "O'nun Zat'ı hariç her șey helâk olucudur...", "Hamd âlemlerin Rabbı olan Allah'a attir..." şeklinde bir kısmını verdiğimiz bu âyetlerde ${ }^{96}$ Allâhü Teâlâ'nın varlığı birliği ve sıfatlarından bazıları konu edinilmektedir. Nûr sûresi 64. âyetle ve Âyetü'l-kürsînnin iki defa yer alması ve "...o birdir şeriki yoktur...", "Bir olan Allah bana yeter." levhaları tevhîd vurgusunu ayrıca öne çlkarmaktadır. ${ }^{97}$

\section{Sonuç}

Tablolar ve kitâbeler, âyet-hadis bütünlügü içerisinde meselelere yaklaşıldığını düşündürtmektedir.

Ayasofya Cami-i Kebîri Şerîfi hat levhaları ve kitâbelerinde dolaylı olarak 6, doğrudan 8 olmak üzere 14 hadisin yer aldığı ve hadislerin tamamının Kütüb-i tis'a eserlerinde kayıtlı olduğu görülmüştür.

Ayasofya Cami-i Kebîri Şerîfi levhaları ve kitâbelerinde çokça hadis metnine yer verilmesi ve Kütüb-i tis'a eserlerinden yer alan metinler olması, dönemin; hadis noktasında hassas, istekli ve koruyucu olduğu kanaatini oluşturmaktadır. Hz. Peygamber'e muhabbetin yoğun olduğu, dindeki konumunun üstün tutulduğu, Sünnet'e bağlllığın güçlü olduğu gözlenmektedir. Çok sayıda hadisin levha ya da kitâbe olarak mabette yer alması dönemin hadise hak ettiği değeri verme gayretinde olduğunu göstermektedir.

Levhâ ve kitâbelerin hem bulunduğu mekânla hem de metinler arası bir mana ilişkisi içerisinde bütünlük arzettiği anlaşılmaktadır. Mâbede müjde hadisi ile girilmektedir. Kelime-i Şehâdet, Kelime-i Tevhid, Besmele, İsmi Celâl, Allah'ı vasfeden ayetler ve Esmâ'ül-Hüsnâ ile Tevhîd inancı vurgulanmaktadır. İsm-i Nebî, Salâtüselâm, Hz. Peygamber'i vasfeden ayetler, hadisi şerif tablo ve kitâbeleri ile Hz. Peygamber'in hayattaki mihmandarlığı öne çıkarılmaktadır. Çehâriyâr-ı güzin ve 'Hasaneyn' levhaları ile de birlik beraberlik, öncü nesiller ve örnek şahsiyetler hatırlatılmaktadır. "Hikmetin başı Allah korkusudur" hadisiyle öne çıkarılan mehâfetullah ilkesi,

95 Recep Ertuğay, Müsteșriklerin Yumuşak Dikeni W. Motgomery Watt'ın İslâm Amentüsüne Yaklaşımı (Kayseri: Kimlik Yayınları, 2017), 46.

96 Fatiha 1/1-7.

97 Sönmez, 53, 207. 
Subhanallahi ve bi hamdihî sübhânellâhilazîm' tesbihi/tezkîri ve kișinin rabbi ile konuşması olan namaz ile canlı tutulmakta, namazgâh olarak mescîdin ehemmiyeti, her iki âlemde af ve afiyet için duâ hatırlatılmaktadir.

İmanı konu edinen metinlerle ferdî hayatın mihengi olarak kalp, saygınlığına yapılan hatırlatmalarla ailevî hayatın mihveri olarak anne, imarının ve inşasının ehemmiyeti vurgusu ile içtimaî hayatın kalbî olarak mescit olmak üzere üç etkin merkezin öne çıkarıldığı gözükmektedir.

\section{Kaynakça}

Aclûnî, İsmâîl b. Muhammed. Keş̧ü'l-hafâ. Kahire: Mektebetü'l-Kuds, 1351.

Ahmed b. Hanbel, Ebû Abdullâh b. Muhammed. Müsned. Nşrr. Şuayb elArnâûd - Âdil Mürşî, Beyrût: Müessesetür-Risâle, 2001.

Akgündüz, Ahmed vd. Üç Devirde Bir Mâbed Ayasofya. İstanbul: Osmanlı Araștırmalı Vakfı Yayınları, 2005.

Alıcı, Mustafa. "Șefâat". Türkiye Diyânet Vakfı İslam Ansiklopedisi.38/41112. İstanbul: Türkiye Diyânet Vakfı Yayınları, 2010.

Arpaguş, Hatice Kelpetin. "Kelime-i Tevhîd". Türkiye Diyânet Vakfı İslam Ansiklopedisi. 25/214-15. İstanbul: TDV Yayınları, 2002.

Beyhâkî, Ahmed b. El-Hüseyin b. Ali b. Mûsa. el-Medhal ile's-süneni'l-kübrâ. Kuveyt: Dârü'l-Hülefâ, ty.

Beyhâkî, Ahmed b. El-Hüseyin b. Ali b. Mûsa. Şuabu'l-îmân. Riyâd: Mektebetü'r-Rüşd, 2003.

Beyhâkî, Ahmed b. El-Hüseyin b. Ali b. Mûsâ Ebûbekir. es-Sünenü'l-kübra. Nşr. Muhammed Abdü'l-Kādir Atâ. Beyrût: Dârü'l-Kitâbi'l-İlmiyye, 2003.

Beyhâkî, Ahmed b. el-Hüseyin b. Alî b. Mûsâ. Delâilü'n-nübüvve. Nşr. Abdulmu'tî yy.: Dârü'l-Kitâbi'l-lilmiyye, 1988.

Buhârî, Ebû Abdullâh Muhammed b. İsmân̂l. Sahîhu'l-Buhârî. İstanbul: Çağrı Yayınları, 1981.

Buhârî, Tahrîcü'l-ehâdîsi'l-merfûâti'l-müsnedeti fî Kitâbi't-târîhi'l-kebir li'lBuhâri. Riyâd: Mektebetü'r-Rüșd, 1999.

Buhârî, Ebû Abdullâh Muhammed b. İsmail. el-Edebü'l-müfred. Riyâd: Mektebetü'l-Meârîf, 1998.

Cafer b. Hayyân, Abdullah b. Muhammed. Kitâbü'l-emsâl fî-ehâdîsi'n-nebevî. Bombay: ed-Dârü's-Selefî, 1987.

Çakan, İsmail Lutfi. "Fetih Hadisi ve Akşemseddîn'in Fetihteki Yeri". Akșemseddin Sempozyumu. 153-163. Ankara: Akşemsettin Vakfı Yayınlarl, 1991. 
Derman, Uğur, ve Mustafa İzzet Uzun. "Besmele". Türkiye Diyânet Vakfı İslâm Ansiklopedisi, İstanbul: TDV Yayınları, 1992. 5/532-37.

TRT DIYANET, Türkiye Radyo Televizyonları Diyanet Televizyonu. "Ayasofya Camii'ne 'Ayasofya-i Kebir Cami-i Şerifi' tabelası asıldı". Erişim 29 Nisan 2021. https://www.diyanethaber.com.tr/ayasofya/ayasofyacamii-ne-ayasofya-i-kebir-cami-i-serifi-h11506.html.

DİB, Diyanet İșleri Başkanlığı. "Ayasofya-i Kebir Cami-i Şerifi Sempozyumu". Erişim 29 Nisan 2021. https://camilerhaftasi.diyanet.gov.tr/trTR/Sempozyum/Icerik//2040/sempozyum

Ebû Dâvûd, Süleyman b. el-Eşas es-Sicistânî. Zühd. 1. Hılvan: Dârü'l-Müşkât, 1993.

Ebû Dâvûd, Sünen. yy.: Dârü'r-Risâleti'l-Arabiyye, 2009.

Ebu Hasan, Ali b. Muhammed b Muhammed b. Habîb el-Basrî. el-Emsâl ve'lhikem. Nşr. Fuad Abdülmünim. Riyâd: Dârüll-Vatan, 1999.

Ebu'l-Hüseyin, Abdülbâkî b. Kāni b. Merzûk b. Vâsık el-Emevî. Nşr. Salih b. Sâlim. Mucemü's-Sahâbe. Medine: Mektebetü'l-Ğürebâ, 1418.

Erûl, Bünyamin. "Çankırı Süleymaniye Camiinde Bulunan Kitâbeler Üzerine Anadolu'da Hadis Geleneği ve Dârü'l-Hadisler Sempozyumu. Ed. Mahmut Düzenli. 369-401. Samsun: Samsun Üniversitesi İlâhiyât Fakültesi Yayınları, 2011.

Ertuğay, Recep. Müsteşriklerin Yumuşak Dikeni W. Motgomery Watt'ın İslâm Amentüsüne Yaklaşımı. Kayseri: Kimlik Yayınları, 2017.

Eyice, Semavi. "Ayasofya". Türkiye Diyânet Vakfı İslam Ansiklopedisi, 206208. İstanbul: Türkiye Diyânet Vakfı Yayınları, 1991.

Fayda, Mustafa. "Hülâfâ-i Râşidîn". Türkiye Diyânet Vakfı İslam Ansiklopedisi. 18/324-38. İstanbul: Türkiye Diyânet Vakfi Yayınları, 1998.

Fayda, "Muhammed". TDV Türkiye Diyânet Vakfi İslam Ansiklopedisi, 30/479-81. İstanbul: Türkiye Diyânet Vakfı Yayınları, 2005.

Görmez, Mehmet vd. Hadislerle İslâm Hadislerin Hadislerle Yorumu. Ankara: Diyanet İşleri Başkanlığı Yayınları, 2013.

Hâkim en-Neysabûri, el-İmam el-Hafız Ebû Abdillah Muhammed b. Abdullâh. Müstedrek ale's-sahihâyn. Nşr. Mustafa Abdülkadir Ata. Beyrut: Dârü'l-Kitâbi'l-İlmiyye, tsz.

Irakî, Ebû'l-Fadl Zeynü'd-Dîn Abdurrahman b. el-Hüseyin b. Abdurrahman. el-Muğnî an hamli'l-esfâr fi'l-esfâr fi tahrîci mâ fill-ïhyâi mine'l-ehbâr. Beyrut: Dâru İbn Hüzeyme, 2005.

İbn Abdi'l-Berr, Ebû Ömer Yûsuf b. Abdullâh b. Muhammed. Nşr. Muhammed el-Becâvi. el-lstiab fi ma'rifeti'l-ashab. Beyrût: Dârü'l-Ceyl, 1992. 
İbn Ebî Şeybe, Abdullah b. Muhammed b. İbrahim b. Osman Ebûbekir. elMusannef fi'l-ehâdîs ve'l-âsârr. Riyâd: Mektebetü'r-Rüșd, 1409.

İbnü'l-Esîr, Ebü'l-Hasen Alî b. Ebi'l-Kerem Muhammed b. Muhammed İzzüddîn. Üstü'l-ğābe fî-marifeti's-sahâbe. Beyrût: Dârü'l-Fikir, 1989.

İbn Hıbbân. Ebu'l-Hasan Alâeddin Ali b. Balabân b. Abdullah. Nşr. Şuayb elArnaûdî. el-İhsan fî takrîb-i Sahîh'í ibn Hibbân. Beyrut: Müessesetü'rRisâle, 1988.

İbn Hacer el-Askalanî, Ebu'l-Fadl Ahmed b. Ali b. Muhammed b. Ahmed. elMetâlibü'l-âliye bi-zevâidi'l-mesânidi's-semâniye. Nşr. Saîd b. Nadır b. Abdü'l-Azîz. Daru'l-Asıme, 1998.

Karaman, Hayreddin vd. Kur'ân yolu: Türkçe Meâl ve Tefsir. Ankara: Diyanet İşleri Başkanlığı, 2007.

Kelebâzî, Ebûbekir Muhammed b. İbrahim b. Yakûb. el-Bahrü'l-fevâid. Nşr. Vecihi Kemalettin Zekî. Kahire: Darü's-Selâm, 2008.

Kıssî, Ebû Muhammed Abdülhamid b. Humeyd b. Nasr. Nşr. Mustafa elAdvî, el-Müntehâb min müsnedi abd $b$. Humeyd. Endülüs: Dâru Belensiye, 2002.

Kulat, Mehmet Ali. “İstanbul'un Fethini Müjdeleyen Hadisin Değerlendirmesi”. Diyane Illmi Dergi. 37/2 (2001), 1-20.

Köktaș, Yavuz. Hadis Tarihi ve Usûlü. Ankara: STS Yayınları, 2017.

Mahmûd Amire, Subhî. el-Muhît fî- ehâdisi'n-nebeviyye ve'l-asar ve's-sünen. Mısır: Dirâsetü'l-İslâmiyye, tsz.

Mahmûd Tahhân, Ebû Hafs Mahmûd b. Ahmed. Teysîrü mustalahi'l-Hadîs. Riyâd: Mektebetü'l-Meârîf, 2010.

Mertoğlu, M. Suat. "Salâtüselâm". Türkiye Diyânet Vakfı İslam Ansiklopedisi. 36/23-24. İstanbul: Türkiye Diyânet Vakfı Yayınları, 2018.

Muhammed, Selâme b Cafer Ebû Abdullâh. Nşr. Hamdi b. Abdulmecit esSelefî. Müsnedü'ş-Şihâb. Beyrut: Müessesetü'r-Risâle, 1986.

Muhammed. İsmâll b. Salâh b. Muhammed el-Hasenî. et-Tenvîr şerhü Câmiü's-săğîr. Nşr. Muhammed İshâk. Riyâd: Mektebetü Dârü's-Selâm, 2011.

Müslim, Ebu'l-Hüseyin el-Haccâc el-Kuşeyrî en-Nisâbûrî. Sahîhu Müslim. Nşr. Halîl Memûn Şeyhâ. Lübnan: Dâru'l-Marife, 2005.

Nesâî, Ebû Abdurrahman b. Şuayb. Sünen. Nşr. Abdü'l-Fettah Ebû Gudde. Halep: Mektebetü'l-Metbûâti'l-İslâmiyye, 1986.

Özler, Mevlüt. "Tevhîd". Türkiye Diyânet Vakfı İslam Ansiklopedisi. 41/1820. İstanbul: Türkiye Diyânet Vakfı Yayınları, 2012. 
Sönmez, Yasemin. "Ayasofya Külliyesi'nin Hat Levhaları ve Kitabeleri”. Konya: Selçuk Üniversitesi Sosyal Bilimler Enstitüsü, 2018.

Subhî, İbrahîm es-Sâlîh. Ulûmu'l-hadîs ve mustalahuhû. Beyrut: Dâru'lİlmi'l-Melâyîn, 1984.

Subhî, Mahmûd Amire. el-Muhît fí- ehâdisi'n-nebeviyye ve'l-Âsar ve's-Sünen. Mısır: Dirâsetü'l-İslâmiyye, tsz.

Taberânî, Süleyman b. Ahmed. el-Mucemü'l-kebîr. Nşr. Hamdi b. Abdü'lMecîd es-Selefî. Kāhire: Mektebetü İbn Teymiye, 1994.

Tirmizî, Ebû Îsa Muhammed b. Îsâ. Sünen. Mısır: Mektebetü ve Matbaatü Mustafa el-Bâyî el-Halebî, 1975.

Topaloğlu, Bekir. "Allah". Türkiye Diyânet Vakfı İslam Ansiklopedisi, İslâm Ansiklopedisi, 2/500-501. İstanbul: Türkiye Diyânet Vakfı Yayınları, 1989.

Yavuz, Yusuf Șevki. "Şefâat". Türkiye Diyânet Vakfi İslam Ansiklopedisi, İslam Ansiklopedisi, 38/412-15. İstanbul: Türkiye Diyânet Vakfı Yayınları 1989.

Yardım, Ali. "Fetih Hadisi Üzerine Bir Araştırma, Diyanet İlmi Dergi, 13/2 (1997), 115-123.

Yeğin, Abdullah vd. Osmanlıca Türkçe Ansiklopedik Büyük Lûgat. İstanbul: Türdav yayınları, 1990.

Zeynüddîn Muhammed el-Medâv Ali b. Zeynülabidîn. et-Teysîr bi-şerh-i Câmii's-sağîr. Riyâd: Mektebetü'l-İmâmü'ş-Şafiî, 1988. 